\title{
1 Determination of Pharmaceuticals in Coastal Systems using 2 Solid Phase Extraction (SPE) followed by Ultra Performance 3 Liquid Chromatography - tandem Mass Spectrometry 4 (UPLC-MS/MS)
}

5 Rosa María Baena-Nogueras ${ }^{\mathrm{a}}$, Marina G. Pintado-Herrera ${ }^{\mathrm{a}}$, Eduardo González-Mazo ${ }^{\mathrm{a}}$ 6 and Pablo A. Lara-Martín*a

${ }^{a}$ Departamento de Química-Física, Facultad de Ciencias del Mar y Ambientales, Universidad de Cádiz, Campus de Excelencia Internacional del Mar (CEI-MAR), Campus de Río San Pedro s/n 11510 Puerto Real, Cádiz, Spain

*Address correspondence to this author at the Department of Physical-Chemistry, Faculty of Environmental and Sea Sciences, Cadiz University, Puerto Real, Cadiz, Spain; Tel/Fax: +34 956016159 , +34956 016040;E-mails: pablo.lara@uca.es.

Abstract: This paper describes the optimization and validation of an analytical method for the determination of 83 pharmaceutically active compounds (PhACs) in aqueous samples using solid-phase extraction (SPE) followed by ultra performance liquid chromatography-triple quadrupole mass spectrometry (UPLC-QqQ-MS/MS). First, several experiments were conducted to optimize different SPE extraction parameters such as $\mathrm{pH}$, elution solvents, and $\mathrm{Na}_{2}$ EDTA addition. Extraction recovery percentages were between 17 and 146\%, being higher than $70 \%$ for 47 target analytes. The method limits of detection (LOD) and quantification (LOQ) were below $1 \mathrm{ng} \mathrm{L}^{-1}$ for most compounds (> 90\%), and the precision of the method, calculated as the relative standard deviation (RSD) of replicate extractions and analyses, was less than $20 \%$. The optimized method was successfully applied to the analysis of real water samples in estuarine and coastal systems from SW Spain (Cadiz Bay and Huelva Estuary). 49 out of 83 target compounds were found in $75 \%$ of samples. Ibuprofen, atenolol, gemfibrozil and caffeine were the most commonly substances detected, reaching concentrations up to $195 \mathrm{ng} \mathrm{L}^{-1}$. These are among the first data available on the occurrence of a wide range of pharmaceuticals in European coastal waters.

Keywords: pharmaceuticals; antibiotics; seawater; mass spectrometry; solid phase extraction; estuary

\section{INTRODUCTION}

Recent studies have demonstrated that a combination of the widespread use of pharmaceuticals (PhACs) and their relative inefficient removal in wastewater treatment plants (WWTPs) leads to the detection of low concentrations of these chemicals (sub-ppb levels) in most sewage-impacted aquatic systems [1-4]. The presence of pharmaceutically active compounds (PhACs) in the receiving waters is concerning as it can represent a threat not only for humans through drinking water intake [5-6] or development of antibiotic-resistant bacteria [7], but also for aquatic organisms [8]. At the same time, chronic and acute toxicity caused by PhACs and other organic micro-contaminants is an open question. Most recent studies have reported behavioral and physiologic alterations in aquatic organisms exposed to sub-lethal concentrations of PhACs during short periods of time [9-11]. The occurrence of long-term effects, however, is still widely unknown, as are the synergism and/or antagonism in toxicity of mixtures and the role of secondary products that could be even more harmful than parent PhACs [12].

The presence of a wide range of PhACs in surface waters at very low concentrations has led to the development of several multiresidue methods for their analysis over the last decade, most of them relying on a preconcentration stage and later determination of target compounds by liquid chromatography-mass spectrometry (LC-MS) [13-16]. The preconcentration step is mandatory not only for achieving lower detection limits but also in order to minimize matrix effects during LC-MS analysis [18-19]. The most commonly used extraction technique for isolation of PhACs is solid phase extraction (SPE) [20-22]. This technique offers the possibility of automation (e.g., online SPE) to minimize sample manipulation and induced errors [5, 23]. Several studies have tested different cartridge types-octadecylsilica (C18), Isolute ENV+, Oasis MCX, Lichrolut EN, and Oasis HLB, among others- for isolating PhACs, all of them showing positive results for some groups such as most anti-inflammatories, lipid regulators or sulfonamides [24-26, 15]. Extraction recoveries reported for the non-polar sorbent C18 have been acceptable for most compounds, but these values are generally $20 \%$ below those obtained with Oasis $\mathrm{HLB}$. Isolute ENV+, on the other hand, is only adequate for a narrow range of substances, mostly polar acidic organic compounds. It is also able to retain some neutral analytes such as macrolide antibiotics, achieving similar recoveries $(80 \%)$ than those for Oasis HLB cartridges [25, 26]. Lichrolut EN has been 
successfully applied for extraction of aqueous samples at neutral $\mathrm{pH}$ but recoveries are poor $(<50 \%)$ for some antibiotics $[24,26]$. Oasis MCX cartridges are not effective [25] unless samples are acidified first, showing an enhancement in recovery percentages between 20 and $40 \%$ for basic drugs such as glibenclamide, trimethoprim and metronidazole [15]. Overall, some sorbents are better for specific compound families such as penicillins, where an improvement of up 36\% for amoxicillin can be observed using Oasis MCX cartridges instead of other sorbents [24]. Psychiatric drugs like fluoxetine show recoveries up to $100 \%$ when employing octadecylsilica cartridges [25]. Better recoveries, however, are often achieved for the majority of tested analytes and conditions (water samples at acid and basic $\mathrm{pH}$ values) using Oasis HLB cartridges, the most popular option when developing multiresidue methods [15].

Regarding LC-MS analysis of PhACs, the most successful technique over the last decade has been the triple quadrupole $(\mathrm{QqQ})$ detector coupled either with high- or ultra-performance liquid chromatography (HPLC/UPLC). This instrument can determine environmentally relevant concentrations (sub-ppb) of organic trace substances such as PhACs via target analysis in multiple reaction monitoring mode (MRM) $[25,27,15]$. However, with increasing sensitivity, high resolution mass spectrometry (HR-MS) instruments (Orbitrap and time-of-flight mass analyzers, or ToF) are used increasingly to analyze a wide range of target and non-target micro-pollutants at trace levels [28]. Several methods using ToF-MS have been recently developed by our group for the analysis of surfactants such as secondary alkane sulfonates (SAS) and nonionic compounds at detection limits below $30 \mathrm{ng} \mathrm{L}^{-1}$ in coastal waters [29, 30]. In addition, Hollender and co-workers [31] have analyzed 220 micropollutants in water using HR-MS, including a variety of pharmaceuticals (sulfonamides, antiinflamatories, and lipid regulators) and pesticides, with detection limits as low as $0.1 \mathrm{ng} \mathrm{L}^{-1}$ for specific chemicals such as trimethoprim, being lower than $120 \mathrm{ng}$ $\mathrm{L}^{-1}$ for most PhACs.

In spite of a significant increase in the number of reports on the environmental distribution and concentrations of PhACs in aquatic systems [32], most of the information is heavily biased towards freshwater systems and WWTP removal efficiency [33,34]. Coastal environments have usually received less attention in the research not only on PhACs but also on other polar organic micropollutants [35-39]. So far, concentrations of up to $50 \mathrm{ng} \mathrm{L}^{-1}$ have been reported for lipid regulators (clofibric acid) and antiinflammatories (diclofenac and ibuprofen) in coastal waters from Taiwan [38]. In addition, near $200 \mathrm{ng} \mathrm{L}$

${ }^{1}$ were detected for carbamazepine in the Baltic Sea and for atenolol in samples from Aegean Sea and Dardanelles in Greece and Turkey, respectively [39]. The behavior and removal of these compounds in coastal systems, however, is not clear, especially in more complex systems such as estuaries, where many processes can influence the reactivity of PhACs [40]. For instance, microbial [41] or sunlight degradation [42] of compounds such as propanolol and indomethacin can shorten their half-lives to < 24 hours. On the other hand, a constant concentration with no decline has been reported for some substances such as sulfamethoxazole and carbamazepine [37, 43, 39] which can be considered as highly persistent wastewater markers in coastal water. The aim of this paper is therefore to provide a better knowledge of the occurrence, concentrations and distribution of a wide range of PhACs in coastal systems. First, we have explored several aspects of the extraction and preconcentration of pharmaceuticals in aqueous samples using SPE under different conditions. Separation, identification and quantification of target pharmaceuticals have been then carried out by a new generation UPLC-QqQ-MS/MS system. Once optimized, the developed method has been applied to the analysis of pharmaceutical residues in surface water samples taken from two different systems located in SW Spain (Cadiz Bay and Huelva Estuary) where no information on these compounds was available.

\section{EXPERIMENTAL SECTION}

\subsection{Material and standards}

Methanol and acetonitrile were of chromatography quality and purchased from Scharlau (Barcelona, Spain); formic acid (98\%), ammonia (25\%), ammonium formate (97.8\%), ammonium acetate (97\%), hydrochloric acid (37\%), sodium hydroxide (98\%), acetic acid $(99 \%)$ and $\mathrm{Na}_{2}$ EDTA $(99 \%)$ were purchased either from Sigma Aldrich (Madrid, Spain) or Panreac (Barcelona, Spain). Water was Milli-Q quality and the solid-phase extraction (SPE) mini-columns used (60 and $500 \mathrm{mg}$ ) were supplied by Waters (Oasis HLB cartridges, Waters Corp., Milford, MA). Analytical standards (> 95\% purity) and deuterated or 13C-labelled surrogates used for quantification were obtained from several suppliers listed in Table 1.

\subsection{Sampling areas}

111 Surface water samples were taken from Cadiz Bay and Huelva Estuary (SW Spain) in October 2011 112 using $2.5 \mathrm{~L}$ pre-washed amber glass bottles. Samples were kept $<4^{\circ} \mathrm{C}$ during their transport to the 
laboratory, where they were filtered using $1 \mu \mathrm{m}$ glass fiber filters (Pall Corporation, Madrid, Spain) and processed immediately. Huelva Estuary is located at the confluence of the Odiel and Tinto rivers (128 and $100 \mathrm{~km}$ long, respectively), which forms a coastal wetland known as Ría of Huelva Estuary. This estuary is within a natural protected area (Marismas del Odiel) and flows into the Atlantic Ocean (37 $7^{\circ} 47.22$ "N, $6^{\circ} 50^{\prime} 51.59$ "). The province of Huelva has 142284 inhabitants and the estuary system covers more than $7000 \mathrm{hm}^{2}$ between counties of Huelva and Punta Umbría (Fig. 1a). This area is also strongly affected by acid mine drainage due to ancient mining activity that produces an important background metal pollution [44]. Cadiz Bay is also situated in the southwest of the Iberian Peninsula and contains five different counties (Cadiz, Chiclana, El Puerto de Santa María, Puerto Real, and San Fernando) with nearly 435000 inhabitants. The area is characterized by coastal marshes, estuaries and tidal creeks such as Río San Pedro and Sancti Petri. In addition, the bay hosts five ports and several shipyards. Most of this marshy area is part of a natural park (Bahía de Cádiz). Guadalete river (157 km long) flows across the province of Cadiz entering the sea in the northern part of the Bay of Cadiz at El Puerto de Santa María (89 068 inhabitants) (Fig. 1b). Most of the terrain adjacent to the river is used for agriculture, and there are also wastewater discharges from a WWTP located upstream [45, 46].

\subsection{Sample extraction and purification by SPE}

Target compounds were extracted from water samples by SPE. Different operational conditions were compared to optimize the extraction method by spiking water aliquots at different concentrations $(1-2.5$ ng $\mathrm{L}^{-1}$ ) using a standard mixture of target substances. First, two Oasis HLB cartridge types were tested (60 and $500 \mathrm{mg}$ ), as well as five different $\mathrm{pH}$ values $(2,4,6,8$ and 10) by adding hydrochloric acid and/or sodium hydroxide to water samples. Additionally, four different amounts of $\mathrm{Na}_{2} \mathrm{EDTA}(0,0.5,1$ and 2.5 $\mathrm{g} \mathrm{L}^{-1}$ ) and five different elution solvents (methanol, acetonitrile, methanol $1 \%$ formic acid, methanol $1 \%$ ammonium acetate and ethylacetate-acetone 1:1) were also tested. All recovery experiments were performed by analyzing spiked water samples in triplicate $(n=3)$.

Once the SPE methodology was optimized, samples from Cadiz Bay and Huelva Estuary were processed by taking two $200 \mathrm{~mL}$ aliquots (one of them acidified to $\mathrm{pH} 2.5$ ) from each surface water sample and spiking them to $50 \mu \mathrm{g} \mathrm{L}^{-1}$ using surrogates (Table 1) prior SPE. HLB cartridges $(500 \mathrm{mg}$ ) were conditioned using $8 \mathrm{~mL}$ of methanol and $8 \mathrm{~mL}$ of water. Thereafter, the samples were passed through the SPE columns at $2 \mathrm{~mL} \mathrm{~min}{ }^{-1}$. The sorbent was washed with $10 \mathrm{ml}$ water and air-dried for 20 min. Elution was performed with pure methanol $(10 \mathrm{~mL})$. The extracts were evaporated under a gentle stream of nitrogen, reconstituted in a methanol/water mixture (25:75) and filtered using $0.22 \mu \mathrm{m}$ polytetrafluoroethylene (PTFE) filters (Teknochroma, Barcelona, Spain).

\subsection{Triple quadrupole mass spectrometry detection}

Analysis of compounds was carried out by UPLC-QqQ-MS/MS using a Bruker EVOQ Elite system

(Bruker, Billerica, MA). The injection volume was set to $10 \mu \mathrm{l}$. The chromatographic separation was performed on a reverse-phase C18 analytical column (Intensity Solo HPLC Column) of $100 \mathrm{~mm}$ x 2.1 $\mathrm{mm}$ and $2 \mu \mathrm{m}$ particle size. Several mobile phases and additives at different concentrations were tested to optimize peak shapes and intensities, as well as chromatographic separation for compounds acquire under both positive and negative electrospray modes (ESI+/-). Aqueous mobile phase additives consisted in formic acid $(0.1,0.01 \%$, and $10 \mathrm{mM})$ and ammonium formate $(10 \mathrm{mM})$ for positive ionization and acetic acid $(0.1 \%$ and $0.01 \%)$, ammonium acetate and ammonia $(5 \mathrm{mM})$ for negative ionization combined with methanol and acetonitrile as organic solvents. The best results were obtained using methanol (solvent A) as organic phase and water with $10 \mathrm{mM}$ of formic acid and ammonium formate or $5 \mathrm{mM}$ of ammonium acetate and ammonia as aqueous phases (solvent B) for ESI- and ESI+, respectively (flow rate $=0.4 \mathrm{~mL}$ $\mathrm{min}^{-1}$ ). The elution gradient for positive mode started at $5 \%$ of solvent $\mathrm{A}$. The percentage of methanol was then increased linearly to $100 \%$ during the first $5 \mathrm{~min}$, and kept at $100 \%$ over $3 \mathrm{~min}$. Total run time was $10 \mathrm{~min}$ including a re-equilibration time of $2 \mathrm{~min}$. Initial conditions were similar operating in negative mode increasing the amount of methanol linearly to $100 \%$ in $2 \mathrm{~min}$, keeping it at $100 \%$ during $4 \mathrm{~min}$ and then, back to initial conditions within 2 min (overall run time $=8 \mathrm{~min}$ ).

The MS system used the following settings: source temperature $=250^{\circ} \mathrm{C}$, probe temperature $=450^{\circ} \mathrm{C}$, cone gas flow $=20 \mathrm{~mL} \mathrm{~min}^{-1}$, probe gas flow $=50 \mathrm{~mL} \mathrm{~min}^{-1}$, nebulizer gas flow $=60 \mathrm{~mL} \mathrm{~min}^{-1}$, collision gas pressure $=2.0$ mTorr. The ion spray voltage was $4500 \mathrm{~V}$ and $4200 \mathrm{~V}$ for ESI+ and ESI- mode, respectively. Standard solutions $\left(1 \mathrm{~g} \mathrm{~L}^{-1}\right)$ of each individual substance were infused to get the optimal collision energy. Optimization of cone voltages was not required unlike in other MS/MS systems [27] as the EVOQ instrument includes a special feature (flat-tunning) that maximizes the sensitivity. MRM transitions were monitored in $2 \mathrm{~min}$ windows to get the highest sensitivity and enough points per chromatographic peak (15). Scan time was at least $12 \mathrm{~ms}$ for each compound, achieving a total scan time 
between 0.6 (ESI-) and $1 \mathrm{~s}$ (ESI+). Identification of compounds was based on comparing their retention times to those previously obtained using standards. In addition, two MRM transitions were used to confirm the compound identity, considering also a deviation in the ion ratio between both transitions lower than $20 \%$. However, only one product ion could be obtained for tetracycline, azithromycin and amitriptyline (Table 1). Quantification was performed using the MRM transition showing the highest intensity and using a calibration curve prepared with standards at concentrations ranging from 0.1 to 100 $\mu \mathrm{g} \mathrm{L}^{-1}$. Deuterated or 13C-labelled compounds were also used to correct for losses during the extraction process and matrix effects. The method limits of detection (mLOD) and quantification (mLOQ) were determined from $200 \mathrm{~mL}$ spiked water samples as the minimum detectable amount of analytes with a signal to noise ratio of 3 and 10 respectively. Instrument limits of detection (iLOD) were also calculated taking into account the amount of sample injected $(10 \mu \mathrm{L})$. The repeatability and reproducibility of the method was checked through three successive injections of the same sample and re-analyzing a batch of samples and standards one week after their first analysis. All the data were acquired and processed using MS Workstation 8.1. Software.

\section{RESULTS AND DISCUSSION}

\subsection{Solid phase extraction optimization for aqueous samples}

Figure 2 shows the SPE extraction efficiencies for some of the most representative target compounds during different experiments. First, Oasis HLB cartridges were chosen based on numerous studies that consider that sorbent optimal when developing a multi-residue method for PhACs [47, 25, 48]. Two different cartridges were compared ( 60 and $500 \mathrm{mg}$ ), and lower recoveries were found for those having 60 $\mathrm{mg}$ of sorbent. This could be due to lower retention of target compounds proportional to the sorbent amount. Two examples are sulfamethazine and indomethazine, whose recovery percentages were reduced by $40 \%$ when using $60 \mathrm{mg}$ cartridges instead of $500 \mathrm{mg}$ (Figs. 2a and b). Once $500 \mathrm{mg}$ Oasis HLB cartridges were considered for the next experiments, the effect of $\mathrm{pH}$ in water samples was tested by selecting a wide range of $\mathrm{pH}$ values (from 2 to 10 ). Better extraction efficiencies were obtained in samples at acid ( $\mathrm{pH} 2-3)$ and neutral $(\mathrm{pH} 7)$ conditions. These results can be explained by considering that many antibiotics present acidic functional groups, therefore lowering $\mathrm{pH}$ by 2 units under their $\mathrm{pKa}$ values enhances the presence of neutral forms and their interaction with the HLB sorbent [49, 1, 22] (Fig. 2c). In this sense, many antibiotic groups considered here showed better results at acid conditions, particularly fluoroquinolones (pKa values between 5 and 6 ) $[20,50,16,51]$. The importance of acidic media for the extraction was also reflected for tetracyclines, increasing their recoveries up to $60 \%$ when comparing with neutral conditions [22]. Accordingly, acid conditions produced an extraction improvement in flumequine (15\%) and tetracycline (27\%) in this study (Figs. 2 b and c). Nevertheless, there is a significant fraction of target $\mathrm{PhACs}$ where no $\mathrm{pH}$ adjustment yields higher extraction efficiencies [25] (Table 2). Keeping neutral $\mathrm{pH}$ proved to be very critical for some substances such as macrolides (erythromycin) and sulfonamides (sulfadimethoxine) [51, 25, 1] as extraction efficiency decreased $\geq 40$ and $90 \%$, respectively, at lower $\mathrm{pH}$ values (Figs. $2 \mathrm{~b}$ and c).

Previous studies pointed out the importance of a cation complexing agent $\left(\mathrm{Na}_{2} \mathrm{EDTA}\right)$ addition to avoid chelation of metals and to minimize interferences for some antibiotics such as macrolides [52] or tetracyclines [53, 17]. The use of acidic elution solvents was also explored. However, extraction efficiencies did not increase significantly $(\mathrm{p}<0.05)$ when $\mathrm{Na}_{2}$ EDTA was added in our case. In fact, there was a decrease up to $15 \%$ in recoveries for tetracycline and albuterol at $\mathrm{pH} 2-3$ and 7 , respectively. Recoveries stayed similar or were even lower for other compounds when EDTA was added. Two examples are erythromycin and indomethacin, whose extraction efficiencies decreased between 46 and $62 \%$ (Fig $2 \mathrm{~b}$ to e). At the end, addition of chelating agent, acid and neutral $\mathrm{pH}$ conditions and methanol as elution solvent was not chosen to achieve higher recovery percentages for most of the PhACs. Table 2 shows the SPE extraction efficiencies for all target compounds once the method was optimized. At least half of the target compounds exhibit recoveries that exceed $80 \%$, and about $80 \%$ of PhACs show extraction efficiencies $\geq 50 \%$. The choice of two different $\mathrm{pH}$ values was justified because of the wide range of compounds selected and their very different physicochemical properties (especially in terms of $\mathrm{pK}_{\mathrm{a}}$ values). This can be illustrated by considering flumequine and chloramphenicol, whose extraction recoveries were $29 \%$ and $50 \%$ higher at acid and neutral $\mathrm{pH}$ values, respectively (Figs. $2 \mathrm{~b}$ and d). Many of the tested drugs, however, were not affected by $\mathrm{pH}$ changes (e.g., trimethoprim, atenolol, amitriptyline), presenting a RSD in their extraction efficiencies $\leq 15 \%$ when comparing both acid and neutral conditions (Figs. 2c and b). The same tendency was observed for other chemicals when considering adding $\mathrm{Na}_{2}$ EDTA, such as tetracycline or chloramphenicol (Figs. $2 \mathrm{c}$ and e). Compared to previous studies, the relatively lower recoveries obtained by our group for cephalosporines are nevertheless comparable to those obtained by other researchers that report similar values for this group (around 40\%) when extracting aqueous samples at neutral $\mathrm{pH}$ [26]. Regarding penicillins, our method has 
improved the extraction efficiency up to $45 \%$ with respect to previous studies using HLB cartridges. Nevertheless, better results for amoxicillin (from 18 to 36\%) and oxacillin (from 17 to $76 \%$ ) could be obtained using Isolut ENV+ cartridges and water at pH 5 instead [54].

\subsection{UPLC-MS/MS separation and determination of PhACs}

Fig. 3 shows two total ion current chromatograms obtained under optimized LC-MS conditions. Several solvents were tested as mobile phase to enhance the separation of target compounds by UPLC and their signal intensity in the mass analyzer. As many of the target compounds are characterized by basic behavior, the acid addition to aqueous mobile phase is commonly accepted [27, 51, 15]. Specifically, we could measure a signal improvement $>70 \%$ for ceftiofur and tetracycline (ESI + ) when using $10 \mathrm{mM}$ of formic acid and ammonium formate buffer $(\mathrm{pH}$ 3.2) as aqueous phase, which ended up being the most appropriate solvent (Fig 3a). Most of the compounds analyzed under positive ionized conditions are usually protonated at low $\mathrm{pH}$ as the interaction between molecules and protons from the aqueous phase that leads to the formation of quasimolecular ion $[\mathrm{M}+\mathrm{H}]^{+}$is enhanced. Sometimes, the most abundant species $[\mathrm{M}+\mathrm{H}]^{+}$were accompanied by adducts such as $\left[\mathrm{M}+\mathrm{NH}_{4}\right]^{+}$(e.g., ivermectin) and $[\mathrm{M}+\mathrm{Na}]^{+}$(e.g., penicillin and monensin) or double charge molecules $[\mathrm{M}+2 \mathrm{H}]^{2+}$ (e.g., spyramicin) (Table 1). On the other hand, sensitivity considerably decreased when the $\mathrm{pH}$ was lowered by adding weak acids in negative ionization mode phase as other studies have already reported [15]. Slightly basic $\mathrm{pH}$ values improve deprotonation of molecules and enhance production of quasimolecular ions $[\mathrm{M}-\mathrm{H}]^{-}$when working in ESI- mode. Thus, we observed a signal decrease of $>50 \%$ and $30 \%$ for triclosan and acethaminophen, respectively, when $0.1 \%$ of acetic acid was added. Increasing $\mathrm{pH}$ in the aqueous mobile phase yielded an appreciable increment in the intensity of peaks (between 50 and $60 \%$ for some compounds such as pravastatin and indomethacin) and improved their shape [27]. Therefore, $5 \mathrm{mM}$ of ammonium acetate and ammonia buffer $(\mathrm{pH} 8)$ was finally selected as the most favorable aqueous solution when operating in negative ionization mode (Fig. 3b). Although peak shapes were enhanced using acetonitrile as organic solvent, methanol led to further enhancement in the signal intensity for most compounds (up to $70 \%$ for azithromycin and metronidazole) so this solvent was preferred over acetonitrile.

Calibration curves from UPLC-QqQ-MS/MS had strong linearity $\left(\mathrm{r}^{2}>0.9\right)$ for all target analytes. The instrumental limits of detection (iLOD) were $<50 \mathrm{pg}$ of the injected amount in $68 \%$ of cases and near $90 \%$ of PhACs considered in this study showed values $<1 \mathrm{ng} \mathrm{L}^{-1}$ for both detection (mLOD) and quantification (mLOQ) limits in real samples (Table 1). Detection and quantification limits were in the same range in other studies showing slightly better results in the present research. Anti-inflammatories $\mathrm{mLOD}$ in our study ranged from $<0.1$ to $1 \mathrm{ng} \mathrm{L}^{-1}$, reaching $2.4 \mathrm{ng} \mathrm{L}^{-1}$ for ketoprofen in a previous study [15]. Other groups, such as beta-blockers or psychiatric drugs followed the same trend being $<0.1 \mathrm{ng} \mathrm{L}^{-1}$ for $99 \%$ of PhACs studied. A notable example could be the mLOD of $7.2 \mathrm{ng} \mathrm{L}^{-1}$ for tetracycline [15], quite separate from that found by this study $\left(1 \mathrm{ng} \mathrm{L}^{-1}\right)$. The reproducibility and repeatability of the method generated RSD of $<20 \%$.

\subsection{Occurrence of PhACs in Huelva Estuary and Cadiz Bay}

To validate de applicability of the optimized analytical method, surface water samples from Huelva estuary and Cadiz bay (both located along the Gulf of Cadiz in SW Spain) were taken to the laboratory and analyzed. Tables 3 and 4 show the concentrations (in $\mathrm{ng} \mathrm{L}^{-1}$ ) of target compounds. Overall, 49 out of 83 pharmaceuticals were detected in $75 \%$ of all collected samples. Their concentrations are usually between one and two orders of magnitude lower than those reported in river waters. For example, atenolol, salicylic acid and trimethoprim [34] were detected in Spanish rivers at levels between 234-1162 $\mathrm{ng} \mathrm{L} \mathrm{L}^{-1}$, significantly higher than those found in our sampling areas $\left(<0.1-40.9 \mathrm{ng} \mathrm{L}^{-1}\right)$. These differences are mostly due to frequent WWTP discharges in most European fresh water systems -often streams impacted by adjacent settlements along their courses- and the enhanced dilution experienced by chemicals once they reach coastal ecosystems. Other factors include weather, number of inhabitants and currents/tides. A more detail study on this topic was published by Benotti and Brownawell [37], where the authors developed a model to estimate the dilution effect in estuarine systems under wet and dry conditions, concluding that dilution is further increased in coastal system as a consequence of heavy rain events. In this sense, the concentration ratio of dry weather/wet weather was 3 and 20 for caffeine and trimethoprim, respectively, whereas other compounds such as nicotine and acetaminophen were below LOD during heavy rain episodes. Despite the dilution effect along the different sampling sites in all these studies, is also evident that concentrations of PhACs significantly increase in those stations located nearby sewage discharge outlets or areas where water circulation is restricted (e.g., M9 and M11 stations in Huelva Estuary). 
Figure 4 summarizes the average concentrations of different groups of antibiotics and other pharmaceuticals (see Table 1 for details on specific compounds per group) in Huelva Estuary and Cadiz Bay. Data on the stimulant caffeine was not included in the figure because of the considerably higher average concentrations measured for this compound (19.4-41.4 $\left.\mathrm{ng} \mathrm{L}^{-1}\right)$ compared to the rest of analytes. These values for caffeine are in agreement with other data from studies in coastal waters $\left(7-87 \mathrm{ng} \mathrm{L}^{-1}\right.$ ) [36]. In fact, this compound has been considered by many authors as an excellent sewage markers that can be detected even in open waters from North Atlantic/Arctic oceans $\left(7-9 \mathrm{ng} \mathrm{L}^{-1}\right)$. Among nonantibiotic PhACs, anti-inflammatories (6.7-9.6 ng L$\left.{ }^{-1}\right)$, beta-blockers $\left(0.6-3.8 \mathrm{ng} \mathrm{L}^{-1}\right)$, lipid regulators (1.1-5.9 $\left.\mathrm{ng} \mathrm{L}^{-1}\right)$, and diuretics $\left(0.6-16 \mathrm{ng} \mathrm{L}^{-1}\right)$ were the most prominent groups of compounds in our sampling areas (Fig. 4b,d). Huelva Estuary usually showed higher concentrations for most of these chemicals than Cadiz Bay. As an example, concentrations near $200 \mathrm{ng} \mathrm{L}^{-1}$ for ibuprofen and in a range of $1.1-69.7 \mathrm{ng} \mathrm{L}^{-1}$ for naproxen, 1.1 to $69.2 \mathrm{ng} \mathrm{L}^{-1}$ for gemfibrozil, and 1.8 to $167.6 \mathrm{ng} \mathrm{L}^{-1}$ for hydrochlorothiazide are in contrast with those measured for these PhACs in Cadiz Bay, which were below $20 \mathrm{ng} \mathrm{L}^{-1}$ at all sampling stations. These differences also occurred for the stimulant caffeine, which presented concentrations over $500 \mathrm{ng} \mathrm{L}^{-1}$ in Huelva and less than $50 \mathrm{ng} \mathrm{L}^{-1}$ in Cadiz. This disparity could be explained by the lower dilution in Huelva Estuary as opposed to the higher volume of water in Cadiz Bay, also more heavily affected by tidal currents. Nevertheless, there were some compounds, especially antibiotics, such as tetracyclines that were only identified in the Cadiz area (0.7-3.5 $\left.\mathrm{ng} \mathrm{L}^{-1}\right)$ and quinolones, that were more prevalent in Huelva Estuary (up to $40 \mathrm{ng} \mathrm{L}^{-1}$ for norfloxacin, ciprofloxacin, and enrofloxacin), suggesting different consumption patterns and/or uses (e.g., aquiculture in Cadiz).

In spite of the scarce information available, we can compare our data with those reported in a few coastal systems in United States and Europe. In general, we can observe that the same groups of PhACs are also predominant in Long Island Sound Estuary (LISE, NY), where average concentrations for antiinflammatories $\left(0.1-50 \mathrm{ng} \mathrm{L}^{-1}\right)$, beta-blockers $\left(0.5-13 \mathrm{ng} \mathrm{L}^{-1}\right)$, lipid regulators $\left(0.2-29 \mathrm{ng} \mathrm{L}^{-1}\right)$, and the diuretic hydrochlorothiazide (10 $\left.\mathrm{ng} \mathrm{L}^{-1}\right)$ were in a similar range of those measured in SW Spain [40]. More specifically, some compounds such as bezafibrate (0.1-1.1 $\left.\mathrm{ng} \mathrm{L}^{-1}\right)$, clofibric acid $\left(0.5-0.6 \mathrm{ng} \mathrm{L}^{-1}\right)$, and diclofenac (2.5-11.8 $\mathrm{ng} \mathrm{L}^{-1}$ ) were within the same order of magnitude in Cadiz Bay, Huelva Estuary and LISE $\left(0.7 \mathrm{ng} \mathrm{L}^{-1}, 0.2 \mathrm{ng} \mathrm{L}^{-1}\right.$ and $4 \mathrm{ng} \mathrm{L}^{-1}$ respectively). Regarding the occurrence of antibiotics, similar concentrations were also found in other estuary systems [43, 40,39], being between 0.4 and $4 \mathrm{ng}$ $\mathrm{L}^{-1}$ for quinolones (e.g., ciprofloxacin) and trimethoprim. On the other hand, there are also significant differences between US and EU regarding the ratios and occurrence of some specific PhACs, which could be attributed to different consumption/prescription patterns and authorized uses (veterinary vs health care). One example is the relatively high concentrations of some anti-inflammatories (e.g., naproxen up to $50 \mathrm{ng} \mathrm{L}^{-1}$ ) and beta-blockers (e.g., metoprolol up to $150 \mathrm{ng} \mathrm{L}^{-1}$ ) that were measured in US West and East coasts $[43,39,40]$, whereas these compounds are not detected in our study area. Antibiotics such as trimethoprim could not be found by Nödler and co-workers [39] but it was detected in more than $50 \%$ of our sampling stations $\left(0.1-2 \mathrm{ng} \mathrm{L}^{-1}\right)$. Regarding Asia, Fang and collaborators [38] analyzed surface coastal waters in Northern Taiwan, screening for some antiinflammatories such as ibuprofen $\left(<2.5-57.1 \mathrm{ng} \mathrm{L}^{-1}\right)$ and diclofenac $\left(<2.5-53.6 \mathrm{ng} \mathrm{L}^{-1}\right)$. These results are in contrast to those reported here from Huelva and Cadiz coastal waters, where concentrations of these compounds are significantly higher for ibuprofen and much lower for diclofenac $\left(0.8-11.8 \mathrm{ng} \mathrm{L}^{-1}\right)$.

\section{CONCLUSION}

This study has contributed to expand the limited information available on the occurrence and distribution of pharmaceuticals in coastal waters. We have presented the optimization of an analytical method for the extraction and determination of 83 pharmaceuticals that includes the use of isotopically labelled compounds, SPE and triple quadrupole mass spectrometry detection. Due to the wide range of analytes considered and their different physicochemical properties, their extraction from aqueous samples was preferred at acid and neutral $\mathrm{pH}$ values to achieve proper recoveries (more than $80 \%$ for half of the compounds). Separation and quantification of target PhACs were also performed in two different runs as different ionization modes (ESI+ and -) were required. Two different buffers (10 $\mathrm{mM}$ of formic acid and ammonium formate, and $5 \mathrm{mM}$ of ammonium acetate and ammonia) were also used as mobile aqueous phases to achieve highest sensitivity and better peak shapes. Once optimized, the method detection limits were within a few $\mathrm{n} \mathrm{L}^{-1}$ or below for all analytes. The application of the method for the analysis of surface water samples from Huelva Estuary and Cadiz Bay (SW Spain) has revealed the predominance of some compounds such as metronidazole (a nitroimidazol at an average concentration of 7-7.8 $\mathrm{ng} \mathrm{L}^{-1}$ ), ofloxacin (a quinolone at 2-3.5 ng L-1), atenolol (a beta-blocker at 0.8-3.7 $\mathrm{ng} \mathrm{L}^{-1}$ ) and several antiinflammatories: ibuprofen (4.3-15.6 $\left.\mathrm{ng} \mathrm{L}^{-1}\right)$, mefenamic acid (5.2-16.8 $\left.\mathrm{ng} \mathrm{L}^{-1}\right)$, fenoprofen (1.9-12.2 $\mathrm{ng} \mathrm{L}^{-}$ ${ }^{1}$ ), and diclofenac (0.8-11.8 $\left.\mathrm{ng} \mathrm{L}^{-1}\right)$. Concentrations of many of the target compounds were consistent with previous studies in other European and American coastal and estuarine systems, but some differences among specific compounds reveals different consumption/uses patterns. 
353 This work has been carried out within a regional research project (RNM 6613) funded by Consejería 354 de Innovación, Ciencia y Empresa (Junta de Andalucía), who also provided a FPI fellowship. 


\section{REFERENCES}

[1] Gros, M.; Petrovic, M.; Barceló, D. Tracing pharmaceutical residues of different therapeutic classes in environmental waters by using liquid chromatography/quadrupole-linear ion trap mass spectrometry and automated library searching. Anal. Chem., 2009, 81(3), 898-912.

[2] Martín, J.; Camacho-Muñoz, D.; Santos, J.L.; Aparicio, I.; Alonso, E. Monitoring of pharmaceutically active compounds on the Guadalquivir River basin (Spain): occurrence and risk assessment. J. Environ.. Monit., 2011, 13(7), $2042-2049$. McArdell, C.S.; Molnar, E.; Suter, M.J.F.; Giger, W. Occurrence and Fate of Macrolide Antibiotics in Wastewater Treatment Plants and in the Glatt Valley Watershed; Switzerland. Environ. Sci. Technol., 2003, 37(24), 5479-5486.

Petrovic, M.; Gros, M.; Barceló, D. Multi-residue analysis of pharmaceuticals in wastewater by ultra-performance liquid chromatography-quadrupole-time-of-flight mass spectrometry. J. Chromatogr. A., 2006, 1124(1-2), 68-81.

López-Serna, R.; Pérez, S.; Ginebreda, A.; Petrovic, M.; Barceló, D. Fully automated determination of 74 pharmaceuthicals in environmental and waste waters by online phase extraction-liquid chromatography-electrospraytandem mass spectrometry. Talanta., 2010, 83(2), 410-424.

Boleda, M.R.; Alechaga, E.; Moyano, E.; Galceran, M.T.; Ventura, F. Survey of the occurrence of pharmaceuticals in Spanish finished drinking waters. Environ. Sci. Pollut. Res., 2014, 21(18), 10917-10939.

Rodríguez-Moraz, S.; Chamorro, S.; Marti, E.; Huerta, B.; Gros, M.; Sànchez-Melsió, A.; Borrego, C.M.; Barceló, D.; Balcázar, J.L. Occurrence of antibiotics and antibiotic resistance genes in hospital and urban wastewaters and their impact on the receiving river. Water Res., 2015, 69, 234-242.

Arnold, K.E.; Brown, A.R.; Ankley, G.T.; Sumpter, J.P. Medicating the environment: assessing risks of pharmaceuticals to wildlife and ecosystems. Phil. Trans. R. Soc. B., 2015, 369(1656), 1-11.

Maranho, L.A.; Garrido-Pérez, R.M.; Baena-Nogueras, R.M.; Lara-Martín, P.A.; Antón-Marín, T.; DelValls, A.; MartínDíaz, M.L. Are WWTPs effluents responsable for acute toxicity? Seasonal variations of sediment quality at the Bay of Cádiz (SW, Spain). Ecotoxicology., 2015a, 24(2), 368-380.

] Parolini, M.; Binelli, A.; Provini, A. Chronic effects induced by ibuprofeno $\mathrm{n}$ the freshwater bivalve Dreissena polymorpha. Ecotoxicol. Environ. Saf., 2011, 74(6), 1586-1594.

1] Maranho, L.A.; Moreira, L.B.; Baena-Nogueras, R.M.; Lara-Martín, P.A.; DelValls, T.A.; Martín-Díaz, M.L. A candidate short-term toxicity test Ampelisca brevicornis to asses sublethal responses to pharmaceuticals bound to marina sediments. Arch. Environ. Contam. Toxicol., 2015b, 68(2), 237-258.

[12] Illés, E.; Takács, E.; Dombi, A.; Gajda-Schrantz, K.; Rácz, G.; Gonter, K.; Wojnárovits, L. Hydroxyl radical induced degradation of ibuprofen. Sci. Total Environ., 2013, 447, 286-292.

[13] Díaz-Cruz, M.; Barceló, D. Determination of antimicrobial residues and metabolites in the aquatic environment by liquid chromatography tandem mass spectrometry. Anal. Bioanal. Chem., 2006, 386(4), 973-985.

[14] López-Serna, R.; Petrovic, M.; Barceló, D. Direct analysis of pharmaceuticals; their metabolites and transformation products in environmental waters using on-line $\mathrm{TurboFlow}^{\mathrm{TM}}$ chromatography-liquid chromatography-tandem mass spectrometry. J. Chromatogr. A. 2012, 1252, 115-129.

[15] Gros, M.; Rodríguez-Moraz, S.; Barceló, D. Fast comprehensive multi-residue analysis of a broad range of human and veterinary pharmaceuticals and some of their metabolites in surface and treated waters by ultra-high-performance liquid chromatography coupled to quadrupole-linear ion trap tandem mass spectrometry. J. Chromatogr. A., 2012, 1248, 104121.

[16] Gros, M.; Rodríguez-Moraz, S.; Barceló, D. Rapid analysis of multiclass antibiotic residues and some of their metabolites in hospital, urban wastewater and river water by ultra-high-performance liquid chromatography coupled to quadrupole-linear ion trap tandem mass spectrometry. J. Chromatogr. A., 2013, 1292, 173-188. 
[20] Renew, J.E.; Ching-Hua, H. Simultaneous determination of fluoroquinolone; sulphonamide; and trimethoprim antibiotics in wastewater using tandem solid phase extraction and liquid chromatography-electrospray mass spectrometry. $J$. Chromatogr. A., 2004, 1042(1-2), 113-121

[21] Abuin, S.; Codoni, R.; Compañó, R.; Granados, M.; Prat, M.D. analysis of macrolide antibiotics in river water by solidphase extraction and liquid chromatography-mass spectrometry. J. Chromatogr. A., 2006, 1114(1), 73-81.

[22] Seifrtová, M.; Nováková, L.; Lino, C.; Pena, A.; Solich, P. An overview of analytical methodologies for the determination of antibiotics in environmental waters. Anal. Chim. Acta., 2009, 649(2), 158-179.

[23] García-Galán, M.J.; Díaz-Cruz, M.S.; Barceló, D. Determination of 19 sulfonamides in environmental water samples by automated on-line solid-phase extraction-liquid chromatography-tandem mass spectrometry (SPE-LC-MS/MS). Talanta, 2010, 81(1-2), 355-366.

[24] Castiglioni, S.; Bagnati, R.; Calamari, D.; Fanelli, R.; Zuccato, E.; A multiresidue analytical method using solid-phase

[25] Gros, M.; Petrovic, M.; Barceló, D. Development of a multi-residue analytical methodology based on liquid chromatography-tandem mass spectrometry (LC-MS/MS) for screening and trace level determination of pharmaceuticals in surface and wastewaters. Talanta, 2006, 70(4), 678-690.

[26] Nageswara Rao, R.; Venkateswarlu, N.; Narsimha, R. Determination of antibiotics in aquatic environment by solid-phase extraction followed by liquid chromatography-electrospray ionization mass spectrometry. J. Chromatogr. A., 2008, 1187(1-2), 151-164.

[27] López-Serna, R.; Petrovic, M.; Barceló, D. Development of a fast instrumental method for the analysis of pharmaceuticals in environmental and wastewater based on ultra-high performance liquid chromatography (UHPLC)tandem mass spectrometry (MS/MS). Chemosphere., 2011, 85(8), 1390-1399.

[28] Hernández, F.; Ibáñez, M.; Bade, R.; Bijlsma, L.; Sancho, J.V. Investigation of pharmaceuticals and illicit drugs in waters by liquid chromatography-high-resolution mass spectrometry. Trends Anal. Chem., 2014, 63, 140-157.

[29] Lara-Martín, P.A.; González-Mazo,; Brownawell, B.J. E. Multi-residue method for the analysis of synthetic surfactants and their degradation metabolites in aquatic systems by liquid chromatography-time-of-flight-mass spectrometry. $J$. Chromatogr. A., 2011, 1218(30), 4799-4807.

[30] Baena-Nogueras, R.M.; Rojas-Ojeda, P.; Sanz, J.L.; González-Mazo, E.; Lara-Martín, P.A. Reactivity and fate of secondary alkane sulfonates (SAS) in marine sediments. Environ. Pollut., 2014, 189; 35-42.

[31] Hollender, J.; Zimmermann, S.G.; Koepke, S.; Krauss, M.; McArdell, C.S.; Ort, C.; Singer, H.; Gunten, U.; Siegrist, H.Elimination of organic micropollutants in a municipal wastewater treatment plant upgraded with a full-scale postozonation followed by sand filtration. Environ. Sci. Technol., 2009, 43(20); 7862-7869.

[32] Hughes, S.R.; Kay, P.; Brown, L.E. Global synthesis and critical evaluation of pharmaceutical data sets collected from river systems. Environ. Sci. Technol, 2013, 47(2), 661-677.

[33] Kasprzyk-Hordern, B.; Dinsdale, R.M.; Guwy, A.J. Multiresidue methods for the analysis of pharmaceuticals, personal care products and illicit drugs in surface water and wastewater by solid-phase extraction and ultra performance liquid chromatography-electrospray tandem mass spectrometry. Anal. Bioanal. Chem., 2008, 391(4), 1293-308.

[34] Ferreira da Silva, B.; Jelic, A.; López-Serna, R.; Mozeto, A.A.; Petrovic, M.; Barceló, D. Occurrence and distribution of pharmaceuticals in surface water, suspended solids and sediments of the Ebro river basin, Spain. Chemosphere, 2011, 85(8), 1331-1339.

[35] Weigel, S.; Kuhlmann, J.; Hühnerfuss, H. Drugs and personal care products as ubiquitous pollutants: occurrence and distribution of clofibric acid; caffeine and DEET in the North Sea. Sci. Total Environ., 2002, 295(1-3), 131-141.

[36] Weigel, S.; Berger; U.; Jensen, E.; Kallenborn, R.; Thorensen, H.; Hühnerfuss, H. Determination of selected pharmaceuticals and caffeine in sewage and seawater from Trømsø/Norway with emphasis on ibuprofen and its metabolites. Chemosphere., 2004, 56(6), 583-592.

[37] Benotti, M.J.; Brownawell, B.J. Distributions of pharmaceuticals in an urban estuary during both dry- and wet-weather conditions. Environ. Sci. Technol., 2007 41(16), 5795-5802.

[38] Fang, T-H.; Nan, F-N.; Chin, T-S.; Feng, H-M. The occurrence and distribution of pharmaceutical compounds in the effluents of a major sewage treatment plant in Northern Taiwan and the receiving coastal waters. Mar. Pollut. Bull., 2012, 64(7), 1435-1444. 
[39] Nödler, K.; Voutsa, D.; Licha, T. Polar organic micropollutants in the coastal environment of different marine systems. Mar. Pollut. Bull., 2014, 85(1), 50-59.

[40] Lara-Martín, P.A.; González-Mazo, E.; Petrovic, M.; Barceló, D.; Brownawell, B.J. Occurrence, distribution and partitioning of non-ionic surfactants and pharmaceuticals in the urbanized Long Island Sound Estuary (NY). Mar. Pollut. Bull, 2014, 85, 710-719.

[41] Benotti, M.J.; Brownawell, B.J. Microbial degradation of pharmaceuticals in estuarine and coastal seawater. Environ. Pollut., 2009, 157(3), 994-1002.

[42] Yamamoto, H.; Nakamura, Y.; Moriguchi, S.; Nakamura, Y.; Honda, Y.; Tamura, I.; Hirata, Y.; Hayashi, A.; Sekizawa, J. Persistence and partitioning of eight selected pharmaceuticals in the aquatic environment: Laboratory photolysis; biodegradation, and sorption experiments. Water Res., 2009, 43(2), 351-362.

[43] Klosterhaus, S.L.; Grace, R.; Hamilton, M.C.; Yee, D. Method validation and reconnaissance of pharmaceuticals, personal care products, and alkylphenols in surface waters, sediments, and mussels in an urban estuary. Environ. Int., 2013, 54, 92-99.

[44] Nieto, J.M.; Sarmiento, A.M.; Olías, M.; Canovas, C.R.; Riba, I.; Kalman, J.; Delvalls, T.A. Acid mine drainage pollution in the Tinto and Odiel rivers (Iberian Pyrite Belt, SW Spain) and bioavailability of the transported metals to the Huelva Estuary. Environ. Int., 2007, 33(4), 445-455.

[45] Lara-Martín, P.A.; Gómez-Parra, A.; González-Mazo, E. Sources, transport and reactivity of anionic and non-ionic surfactants in several aquatic ecosystems in SW Spain: a comparative study. Environ. Pollut., 2008, 156(1), 36-45.

[46] Baena-Nogueras, R.M.; González-Mazo, E.; Lara-Martín, P.A. Determination and occurrence of secondary alkane sulfonates (SAS) in aquatic environments. Environ. Pollut., 2013, 176; 151-157.

[47] Ferdig, M.; Kaleta, A.; Thanh, Vo; T.D.; Buchberger, W. Improved capillary electrophoretic separation of nine (fluoro)quinolones with fluorescence detection for biological and environmental samples. J. Chromatogr. A., 2004 1047(2), 305-311.

[48] Fatta, D.; Nikolaou, A.; Achilleos, A.; Meriç, S. Analytical methods for tracing pharmaceutical residues in water and wastewater. Trends Anal. Chem., 2007, 26(6), 515-533.

[49] Hao, C.; Zhao, X.; Tabe, S.; Yang, P. Optimization of a multiresidual method for the determination of waterborne emerging organic pollutants using-phase extraction and liquid chromatography/tandem mass spectrometry and isotope dilution mass spectrometry. Environ. Sci. Technol., 2008, 42(11), 4068-4075.

[50] Ferdig, M.; Kaleta, A.; Buchberger,W. Improved liquid chromatographic determination of nine currently used (fluoro)quinolones with fluorescence and mass spectrometric detection for environmental samples. J. Sep. Sci., 2005, 28(13), 1448-1456.

[51] Dorival-García, N.; Zafra-Gçomez, A.; Cantarero, S.; Navalón, A.; Vílchez, J.L. Simultaneous determination of 13 quinolones antibiotic derivatives in wastewater samples using solid-phase extraction and ultra performance liquid chromatography-tandem mass spectrometry. Microchem. J., 2013, 106, 323-333.

[52] Yang, S.; Carlson, K.H. Solid-phase extraction-high-performance liquid chromatography-ion trap mass spectrometry for analysis of trace concentrations of macrolide antibiotics in natural and waste water matrices. J. Chromatogr. A., 2004, $1038(1-2), 141-155$.

[53] Zhu, J.; Snow, D.D.; Cassada, D.A.; Monson, S.J.; Spalding, R.F. Analysis of oxytetracycline, tetracycline; and chlortetracycline in water using solid-phase extraction and liquid chromatography-tandem mass spectrometry. $J$. Chromatogr. A., 2001, 928(), 177-186. 


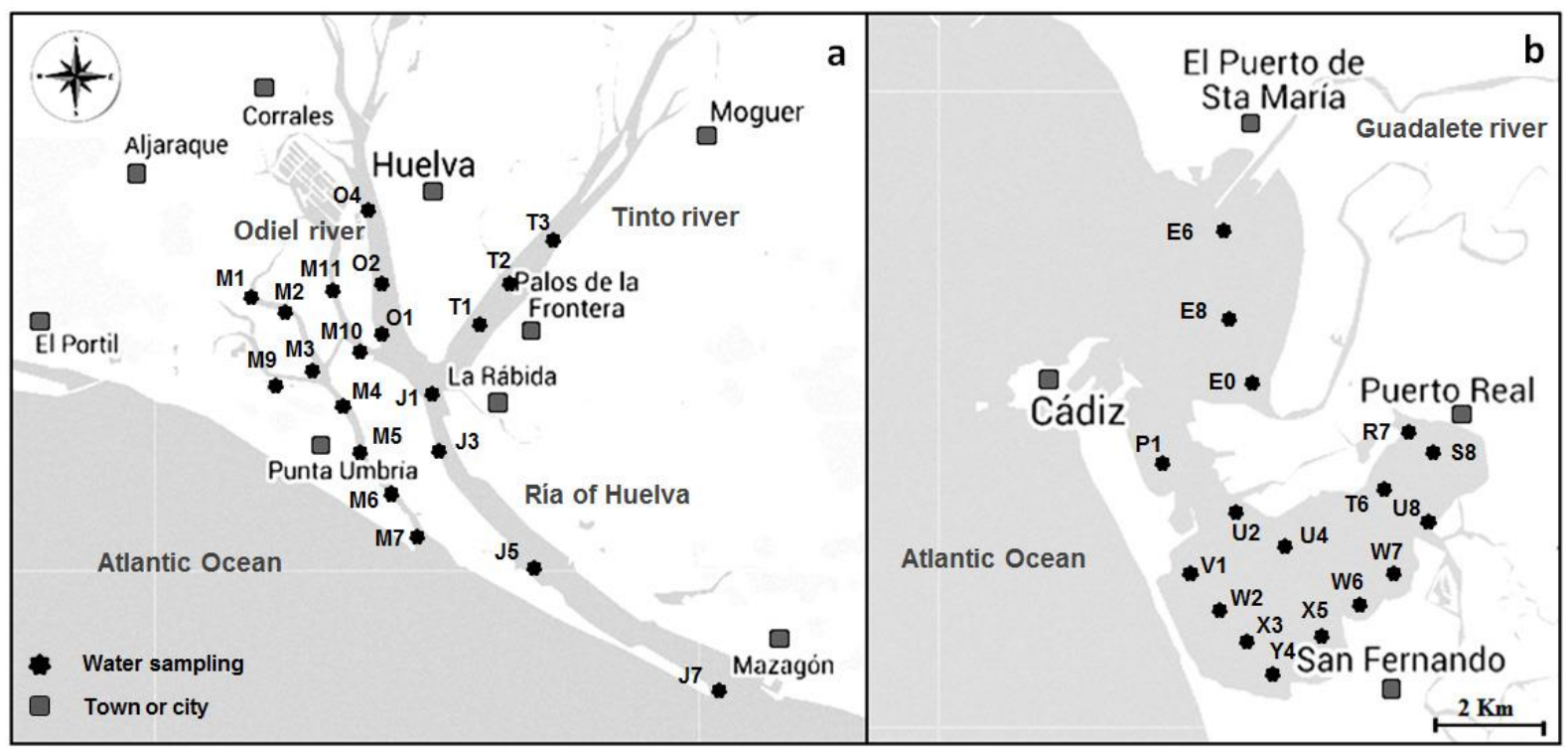

505 Figure 1. Map showing the location of the sampling stations along the Gulf of Cadiz in Huelva Estuary

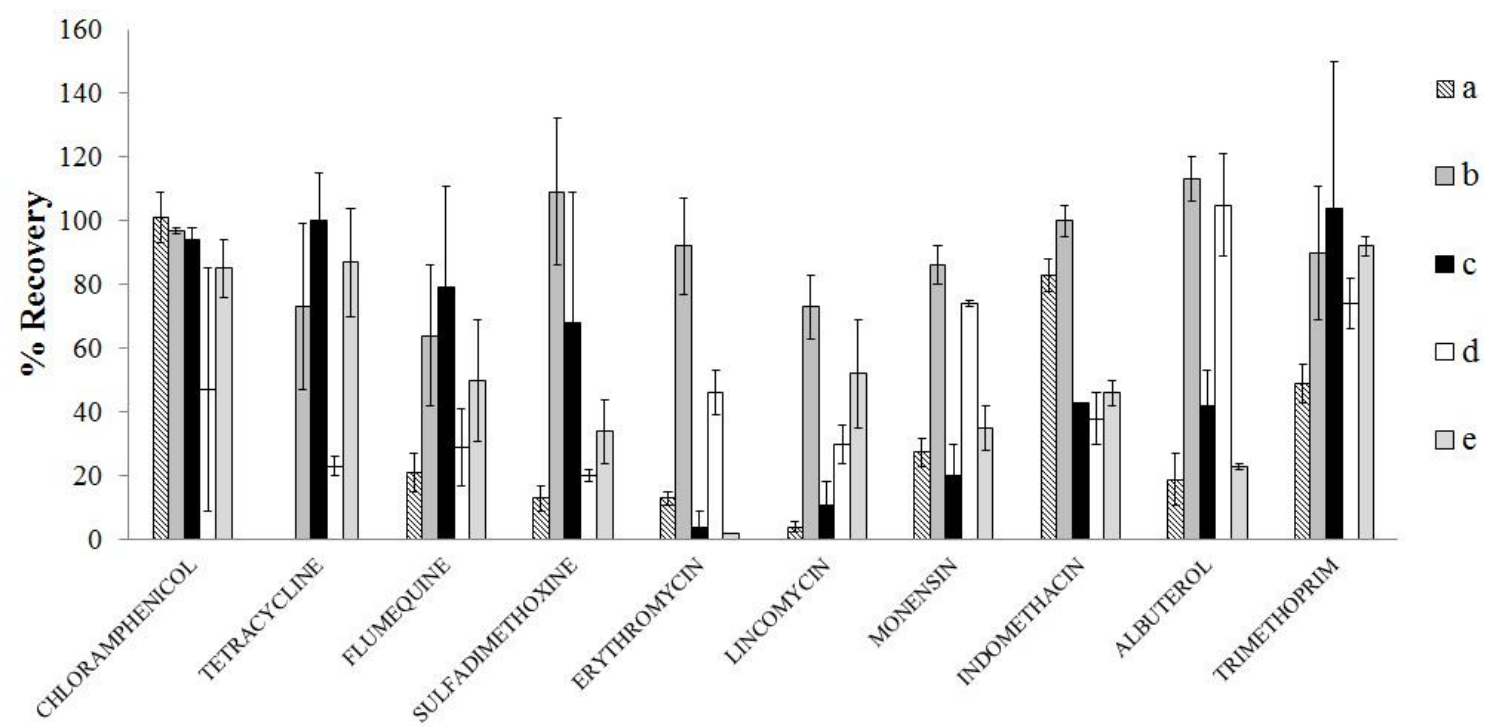

Figure 2. Optimized SPE parameters, a) pH 7 using 60 mg cartridge and elution using methanol; b) pH 7 using $500 \mathrm{mg}$ cartridge and elution using methanol; c) pH 2 using $500 \mathrm{mg}$ cartridge and elution using methanol; d) pH 7 using $500 \mathrm{mg}$ cartridge, adding 1g of EDTA and elution using methanol $1 \%$ formic acid; e) $\mathrm{pH} 2$ using $500 \mathrm{mg}$ cartridge, adding $1 \mathrm{~g}$ of EDTA and elution using methanol with $1 \%$ formic acid. 
516

517

518

519

520

521

522

523

524

525

526

527

528

529

530

531

532

533

534

535

536

537

538

539

540

541

542

543

544

545

546

547

548

549

550

551

552

553

554

555

556
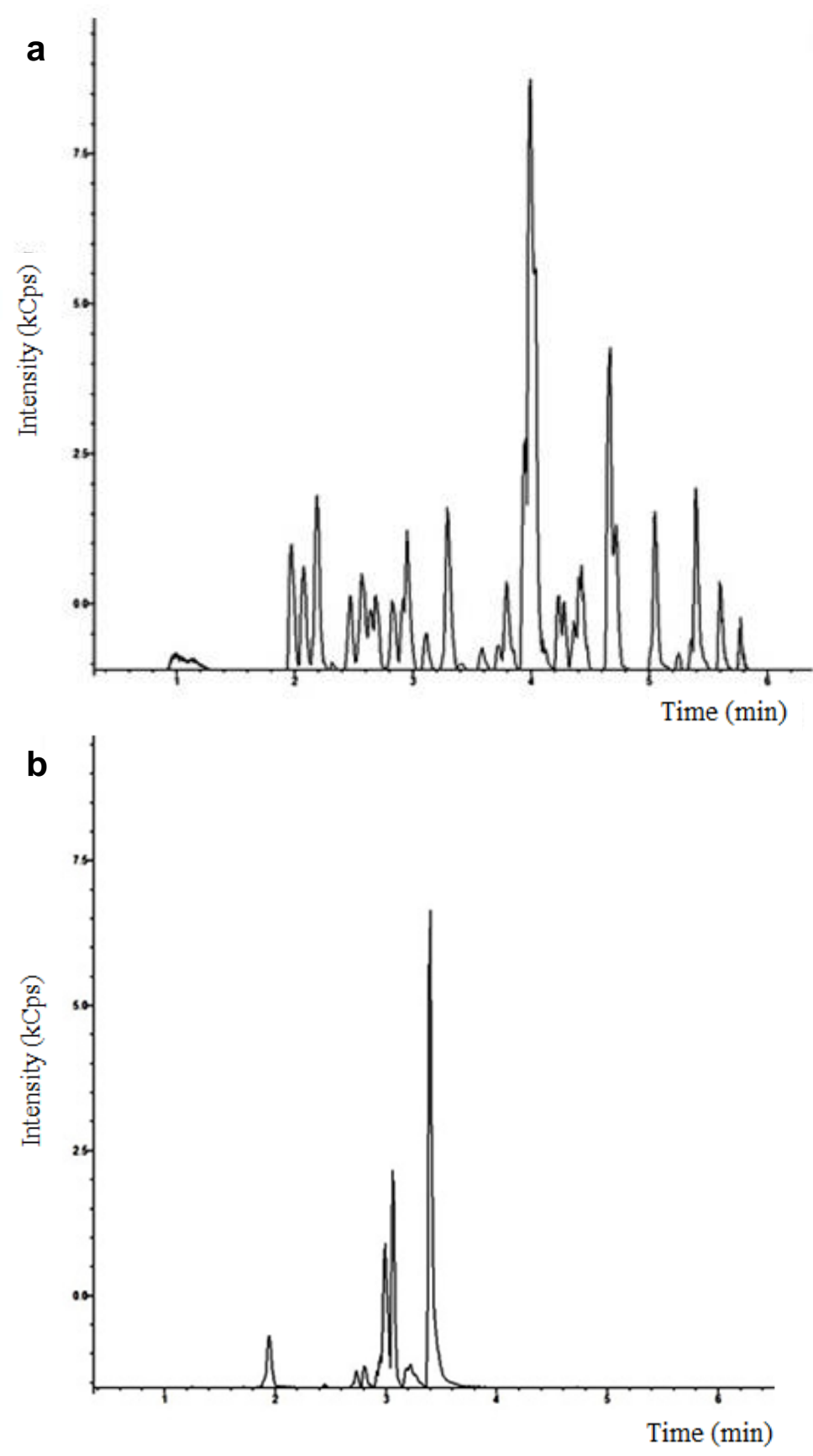

Figure 3. Representative total ion current (TIC) chromatograms of a $25 \mathrm{ng} \mathrm{mL}^{-1}$ standard mixture of the compounds analyzed under positive (a) and negative (b) ionization. 
557

558

559

560

561

562

563

564

565

566

567

568

569

570

571

572

573

574

575

576

577

578

579

580

581

582
Huelva
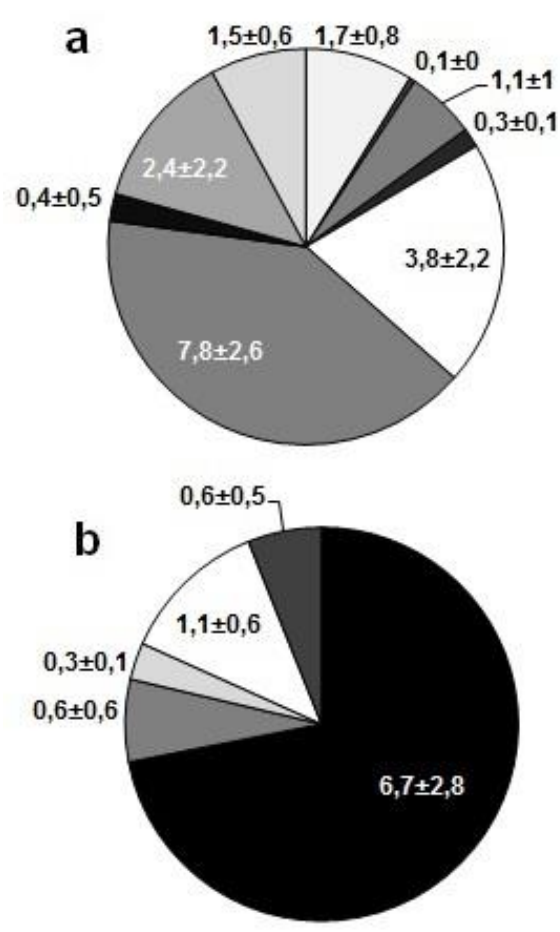

Cadiz

c

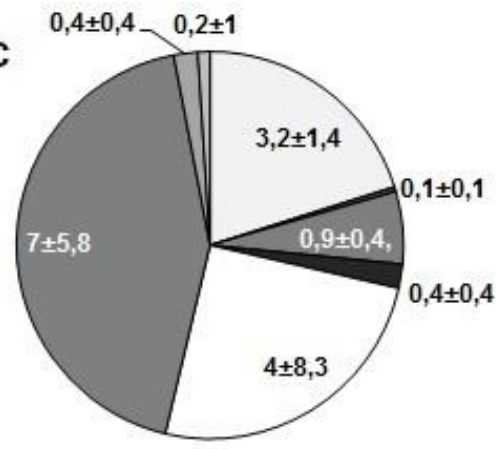

口AMPHENICOLS

- MACROLIDES

口 LINCOSAMIDES

- SULFONAMIDES

口QUINOLONES

$\square$ NITROIMIDAZOLES

口 OTHERANTIBIOTICS

$\square$ DESINFECTANTS

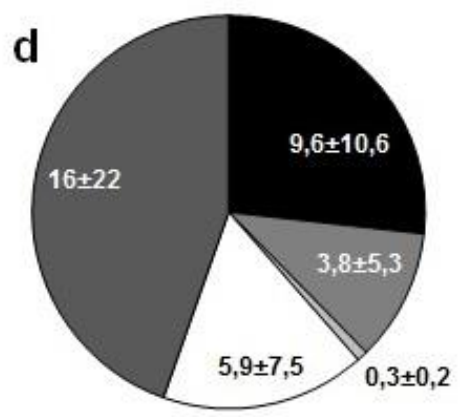

- ANTIINFLAM MATORIES

$\square$ BETA-BLOCKERS

$\square$ PSYQUIATRIC DRUGS

$\square$ LIPID REGULATORS

口DIURETICS

Figure 4. Average concentrations (in $\mathrm{ng} \mathrm{L}^{-1}$ ) of $(\mathrm{a}, \mathrm{c})$ antibiotics and $(\mathrm{b}, \mathrm{d})$ PhACs in Huelva Estuary and the Bay of Cadiz, respectively. 
Table 1. UPLC-MS/MS parameters (ionization mode, retention time, MRM transitions and limits of detection) for the analysis of target PhACs and their corresponding isotopically labelled compounds. Suppliers are also indicated.

\begin{tabular}{|c|c|c|c|c|c|c|c|}
\hline PhACs group & Compound & $\begin{array}{c}\mathbf{t}_{\mathbf{R}} \\
(\mathrm{min}) \\
\end{array}$ & MRM & $\begin{array}{c}\text { Collision } \\
\text { Energy } \\
\end{array}$ & $\begin{array}{c}\text { iLOD } \\
(\mathrm{pg})\end{array}$ & $\begin{array}{l}\text { mLOD } \\
\left(n g L^{-1}\right) \\
\end{array}$ & $\begin{array}{l}\operatorname{mLOQ} \\
\left(\mathrm{ng} \mathrm{L}^{-1}\right) \\
\end{array}$ \\
\hline \multirow{8}{*}{ Penicillins } & $\operatorname{Amoxicillin}^{\mathrm{a} 1}(+)$ & 1.77 & $366.10>349.20$ & 6 & 309,3 & 0,9 & 2,9 \\
\hline & & & $366.10>114.30$ & 20 & & & \\
\hline & Penicillin- $\mathrm{G}^{\mathrm{a} 1}(+)$ & 3.64 & $357.00>198.20 *$ & 12 & 681,8 & 0,4 & 1,3 \\
\hline & & & $357.00>182.00$ & 14 & & & \\
\hline & Oxacillin $^{\mathrm{a} 1}(+)$ & 3.89 & $402.10>160.40$ & 11 & 16,1 & $<0.1$ & 0,2 \\
\hline & & & $402.10>243.40$ & 11 & & & \\
\hline & Ampicillin $^{\mathrm{a} 1}(+)$ & 2.72 & $350.10>106.30$ & 15 & 5,0 & $<0.1$ & $<0.1$ \\
\hline & & & $350.10>160.40$ & 11 & & & \\
\hline \multirow{10}{*}{ Cephalosporins } & Cefaclor $^{\mathrm{a} 1}(+)$ & 2.58 & $368.00>174.40$ & 13 & 10,3 & $<0.1$ & $<0.1$ \\
\hline & & & $368.00>106.40$ & 19 & & & \\
\hline & Cefdinir $^{\mathrm{a} 1}(+)$ & 2.31 & $396.00>227.10$ & 11 & 69,8 & 0,1 & 0,3 \\
\hline & & & $396.00>126.10$ & 26 & & & \\
\hline & Ceftiofur $^{\mathrm{a} 1}(+)$ & 3.34 & $524.04>241.20$ & 15 & 15,5 & $<0.1$ & 0,1 \\
\hline & & & $524.04>209.90$ & 22 & & & \\
\hline & Cefadroxil $^{\text {al }}(+)$ & 1.82 & $363.30>114.30$ & 13 & 21,5 & $<0.1$ & 0,1 \\
\hline & & & $363.30>208.30$ & 8 & & & \\
\hline & Cefquinome $^{\mathrm{a} 1}(+)$ & 2.39 & $529.00>134.40$ & 13 & 34,1 & $<0.1$ & $<0.1$ \\
\hline & & & $529.00>396.40$ & 9 & & & \\
\hline \multirow{7}{*}{ Tetracyclines } & Doxycicline $^{\mathrm{a} 2}(+)$ & 2.91 & $445.20>410.40$ & 21 & 142,6 & 0,2 & 0,5 \\
\hline & & & $445.20>267.60$ & 35 & & & \\
\hline & Oxytetracycline $^{\mathrm{a} 2}(+)$ & 2.99 & $461.10>425.20$ & 20 & 72,8 & $<0.1$ & 0,1 \\
\hline & & & $461.10>426.90$ & 19 & & & \\
\hline & Chlortetracycline $^{\mathrm{a} 2}(+)$ & 3.43 & $479.10>444.10$ & 20 & 24,0 & $<0.1$ & 0,1 \\
\hline & & & $479.10>462.10$ & 15 & & & \\
\hline & Tetracycline $^{\mathrm{a} 2}(+)$ & 3.67 & $445.20>428.20$ & 10 & 2097,9 & 1,0 & 3,5 \\
\hline \multirow{4}{*}{ Amphenicols } & Tiamulin $^{\text {a1 }}(+)$ & 4.05 & $494.30>191.40$ & 19 & 4,4 & $<0.1$ & $<0.1$ \\
\hline & & & $494.30>193.10$ & 19 & & & \\
\hline & Chloramphenicol $^{\mathrm{a} 1}(-)$ & 2.73 & $321.00>152.10$ & 16 & 14,3 & $<0.1$ & $<0.1$ \\
\hline & & & $321.00>257.50$ & 8 & & & \\
\hline \multirow{12}{*}{ Macrolides } & Erythromycin $^{\mathrm{a} 3}(+)$ & 4.16 & $734.50>158.20$ & 31 & 66,6 & $<0.1$ & 0,1 \\
\hline & & & $734.50>575.40$ & 20 & & & \\
\hline & Clarithromycin ${ }^{\mathrm{a} 3}(+)$ & 4.49 & $748.48>158.10$ & 26 & 0,4 & $<0.1$ & $<0.1$ \\
\hline & & & $748.48>590.20$ & 18 & & & \\
\hline & Azithromycin ${ }^{\mathrm{a} 3}(+)$ & 4.43 & $748.90>591.40$ & 26 & 1,0 & $<0.1$ & $<0.1$ \\
\hline & & & & & & & \\
\hline & Roxithromycin ${ }^{\mathrm{a} 3}(+)$ & 4.51 & $837.50>158.30$ & 32 & 1,7 & $<0.1$ & $<0.1$ \\
\hline & & & $837.50>679.50$ & 20 & & & \\
\hline & $\operatorname{Spiramycin}^{\mathrm{a} 3}(+)$ & 3.40 & $422.00>174.30^{*}$ & 20 & 74,3 & 0,1 & 0,5 \\
\hline & & & $422.00>101.20$ & 18 & & & \\
\hline & Tylosin ${ }^{\mathrm{a} 3}(+)$ & 4.08 & $916.50>174.20$ & 39 & 6,8 & $<0.1$ & $<0.1$ \\
\hline & & & $916.50>771.80$ & 29 & & & \\
\hline \multirow{12}{*}{ Lincosamides } & Lincomycin $^{\mathrm{a} 1}(+)$ & 2.66 & $407.20>126.30$ & 24 & 0,6 & $<0.1$ & $<0.1$ \\
\hline & & & $407.20>359.40$ & 16 & & & \\
\hline & Clindamycin $^{\mathrm{a} 1}(+)$ & 3.83 & $425.20>126.30$ & 26 & 5,4 & $<0.1$ & $<0.1$ \\
\hline & & & $425.20>377.40$ & 16 & & & \\
\hline & Sulfamethazine ${ }^{a 4}(+)$ & 2.72 & $279.10>186.20$ & 19 & 26,8 & $<0.1$ & 0,1 \\
\hline & & & $279.10>92.30$ & 32 & & & \\
\hline & Sulfamethizole $^{\mathrm{a} 4}(+)$ & 2.64 & $271.03>156.10$ & 13 & 25,0 & $<0.1$ & 0,1 \\
\hline & & & $271.03>92.40$ & 29 & & & \\
\hline & Sulfathiazole $^{\mathrm{a} 4}(+)$ & 2.26 & $256.02>156.20$ & 14 & 2,2 & $<0.1$ & $<0.1$ \\
\hline & & & $256.02>108.30$ & 23 & & & \\
\hline & Sulfadiazine $^{\mathrm{a} 4}(+)$ & 2.09 & $251.06>155.20$ & 15 & 11,5 & $<0.1$ & $<0.1$ \\
\hline & & & $251.06>92.30$ & 26 & & & \\
\hline
\end{tabular}




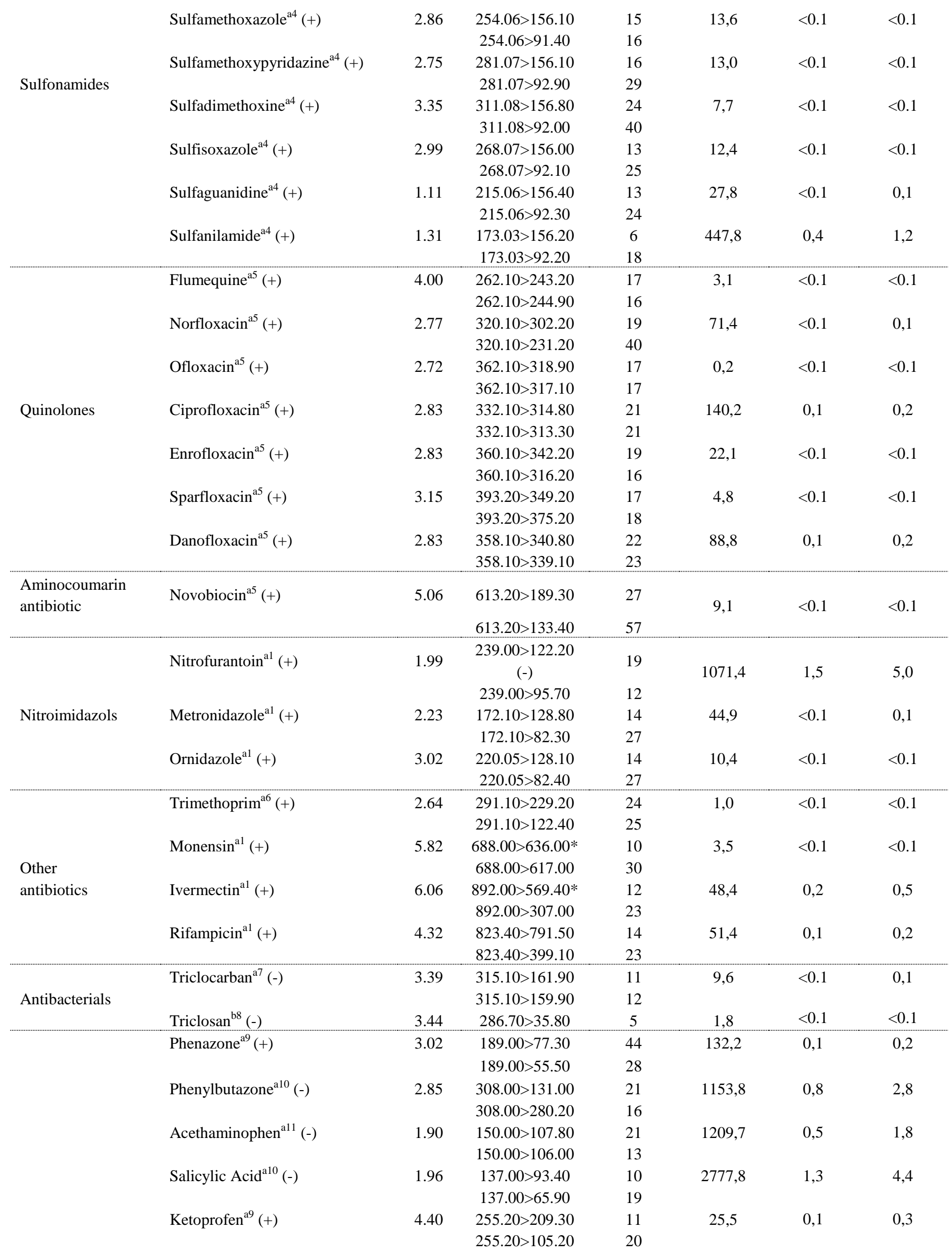




\begin{tabular}{|c|c|c|c|c|c|c|c|}
\hline \multirow[t]{12}{*}{ Antiinflammatories } & Naproxen $^{\mathrm{a} 10}(-)$ & 2.73 & $229.10>169.10$ & 16 & 595,2 & 0,3 & 0,9 \\
\hline & & & $229.10>185.20$ & 4 & & & \\
\hline & Ibuprofen $^{\text {a12 }}(-)$ & 2.96 & $205.10>160.00$ & 5 & 2272,7 & 1,0 & 3,5 \\
\hline & & & $205.10>162.10$ & 5 & & & \\
\hline & Fenoprofen $^{\mathrm{a} 10}(-)$ & 2.90 & $241.10>197.10$ & 5 & 351,3 & 0,1 & 0,5 \\
\hline & & & $241.10>93.40$ & 32 & & & \\
\hline & Indomethacin $^{\mathrm{a} 10}(-)$ & 2.96 & $358.10>312.10$ & 6 & 1239,7 & 0,6 & 2,1 \\
\hline & & & $356.10>297.20$ & 14 & & & \\
\hline & Diclofenac $^{\mathrm{a} 10}(-)$ & 2.93 & $294.00>250.00$ & 7 & 113,2 & 0,1 & 0,2 \\
\hline & & & $294.00>36.00$ & 22 & & & \\
\hline & Mefenamic $\operatorname{acid}^{\mathrm{a} 10}(-)$ & 2.96 & $240.10>196.90$ & 14 & 11,8 & $<0.1$ & $<0.1$ \\
\hline & & & $240.10>180.10$ & 23 & & & \\
\hline \multirow{12}{*}{ Beta-blockers } & Atenolol $^{\mathrm{a} 1}(+)$ & 2.01 & $267.19>145.10$ & 28 & 2,5 & $<0.1$ & $<0.1$ \\
\hline & & & $267.19>72.80$ & 22 & & & \\
\hline & Metoprolol $^{\mathrm{a} 1}(+)$ & 3.15 & $268.40>116.20$ & 17 & 94,9 & 0,1 & 0,2 \\
\hline & & & $268.40>74.20$ & 20 & & & \\
\hline & Propanolol $^{\mathrm{a} 1}(+)$ & 3.80 & 260.10116 .20 & 17 & 33,3 & $<0.1$ & 0,1 \\
\hline & & & $260.10>72.90$ & 21 & & & \\
\hline & Timolol $^{\mathrm{a} 1}(+)$ & 3.18 & $317.10>261.10$ & 15 & 0,4 & $<0.1$ & $<0.1$ \\
\hline & & & $317.10>74.40$ & 22 & & & \\
\hline & Nadolol $^{\mathrm{a} 1}(+)$ & 2.72 & $310.20>254.20$ & 16 & 2,8 & $<0.1$ & $<0.1$ \\
\hline & & & $310.20>201.10$ & 22 & & & \\
\hline & Pindolol $^{\mathrm{a} 1}(+)$ & 2.50 & $249.10>116.90$ & 17 & 39,3 & $<0.1$ & 0,1 \\
\hline & & & $249.10>115.40$ & 16 & & & \\
\hline \multirow{4}{*}{$\begin{array}{l}\text { Histamine } \\
\text { receptor antagonist }\end{array}$} & Famotidine $^{\mathrm{a} 1}(+)$ & 2.07 & $338.00>189.80$ & 19 & 16,5 & $<0.1$ & 0,1 \\
\hline & & & $338.00>188.20$ & 19 & & & \\
\hline & Ranitidine $^{\mathrm{a} 1}(+)$ & 2.01 & $315.00>129.40$ & 31 & 18,9 & $<0.1$ & 0,1 \\
\hline & & & $315.00>130.80$ & 31 & & & \\
\hline \multirow{7}{*}{$\begin{array}{l}\text { Psychiatric drugs } \\
\text { and estimulants }\end{array}$} & Carbamazepine $^{\mathrm{a} 13}(+)$ & 4.05 & $237.10>193.80$ & 22 & 7,6 & $<0.1$ & $<0.1$ \\
\hline & & & $237.10>192.40$ & 31 & & & \\
\hline & Fluoxetine $^{\mathrm{a} 14}(+)$ & 4.32 & $310.10>44.60$ & 10 & 3,9 & $<0.1$ & $<0.1$ \\
\hline & & & $310.10>148.40$ & 7 & & & \\
\hline & Amitriptiline $^{\mathrm{a} 13}(+)$ & 4.29 & $278.20>91.20$ & 27 & 47,9 & $<0.1$ & 0,1 \\
\hline & Caffeine $^{\mathrm{a} 1}(+)$ & 2.72 & $195.10>137.30$ & 17 & 105,6 & 0.1 & 0.3 \\
\hline & & & $195.10>138.90$ & 18 & & & \\
\hline \multirow{11}{*}{ Lipid Regulators } & Clofibric acid ${ }^{\text {a15 }}(-)$ & 2.76 & $213.03>127.90$ & 12 & 106,8 & 0.1 & 0,2 \\
\hline & & & $213.03>85.50$ & 10 & & & \\
\hline & Gemfibrozil $^{\mathrm{a} 15}(-)$ & 3.04 & $249.10>120.70$ & 11 & 11,8 & $<0.1$ & $<0.1$ \\
\hline & & & $249.10>121.70$ & 11 & & & \\
\hline & Fenofibrate $^{\mathrm{a} 15}(+)$ & 5.46 & $361.10>232.00$ & 15 & 6,2 & $<0.1$ & 0,1 \\
\hline & & & $361.10>139.20$ & 27 & & & \\
\hline & Bezafibrate $^{\mathrm{a} 15}(-)$ & 2.82 & $360.10>274.20$ & 14 & 2,3 & $<0.1$ & $<0.1$ \\
\hline & & & $360.10>85.50$ & 13 & & & \\
\hline & Pravastatin $^{\text {a15 }}(-)$ & 2.76 & $423.00>101.90$ & 26 & 50,6 & $<0.1$ & 0,1 \\
\hline & & & $423.00>100.40$ & 25 & & & \\
\hline & Hydrochloroth. ${ }^{\text {a18 }}(-)$ & 1.73 & $295.90>269.10$ & 17 & 4,3 & $<0.1$ & $<0.1$ \\
\hline \multirow{3}{*}{ Diuretics } & & & $295.90>205.20$ & 22 & & & \\
\hline & Furosemide $^{\mathrm{a} 1}(-)$ & 2.47 & $328.90>205.00$ & 20 & 18,6 & $<0.1$ & $<0.1$ \\
\hline & & & $328.90>285.10$ & 12 & & & \\
\hline \multirow{8}{*}{$\begin{array}{l}\text { Other } \\
\text { PhACs }\end{array}$} & Albuterol $^{\mathrm{a} 16}(+)$ & 2.01 & $240.10>148.20$ & 17 & 64,4 & $<0.1$ & 0,1 \\
\hline & & & $240.10>222.30$ & 7 & & & \\
\hline & Glibenclamide $^{\text {a17 }}(+)$ & 4.76 & $494.10>369.20$ & 12 & 1,8 & $<0.1$ & $<0.1$ \\
\hline & & & $494.10>169.10$ & 38 & & & \\
\hline & Metotrexate $^{\mathrm{a} 1}(+)$ & 2.50 & $455.18>175.20$ & 47 & 29,4 & $<0.1$ & 0,1 \\
\hline & & & $455.18>307.10$ & 24 & & & \\
\hline & 1.Atenolol-d ${ }_{7}^{\mathrm{d}}(+)$ & 2.01 & $274.20>146.00$ & 26 & & & \\
\hline & & & $274.20>144.50$ & 26 & & & \\
\hline
\end{tabular}




\begin{tabular}{|c|c|c|c|c|}
\hline & 2.Demeclocycline ${ }^{\mathrm{a}}(+)$ & 3.15 & $465.10>448.10$ & 17 \\
\hline & & & $465.10>430.20$ & 23 \\
\hline & 3.Erythromycin- $d_{3}{ }^{a}(+)$ & 4.16 & $738.90>162.00$ & 33 \\
\hline & & & $738.90>581.10$ & 20 \\
\hline & 4. Sulfadimethoxine $-\mathrm{d}_{6}{ }^{\mathrm{a}}(+)$ & 3.34 & $317.40>155.80$ & 19 \\
\hline & & & $317.40>92.00$ & 29 \\
\hline & 5.Ofloxacin- $\mathrm{d}_{3}{ }^{\mathrm{a}}(+)$ & 2.72 & $365.20>261.00$ & 30 \\
\hline & & & $365.20>320.90$ & 18 \\
\hline & 6.Trimethoprim- $\mathrm{d}_{9}{ }^{\mathrm{a}}(+)$ & 2.58 & $301.00>235.10$ & 25 \\
\hline & & & $301.00>123.90$ & 25 \\
\hline & 7. Triclocarban ${ }^{13} \mathrm{C}_{6}{ }^{\mathrm{f}}(-)$ & 3.39 & $319.00>159.90$ & 12 \\
\hline & & & $321.00>161.90$ & 15 \\
\hline & 8.Triclosan- $\mathrm{d}_{3}{ }^{\mathrm{b}}(-)$ & 3.44 & $291.60>35.50$ & 5 \\
\hline & 9.Phenazone- $\mathrm{d}_{3}^{\mathrm{d}}(+)$ & 3.02 & $192.00>59.30$ & 24 \\
\hline Isotopically & & & $192.00>77.20$ & 34 \\
\hline labelled & 10.Naproxen methoxy- $\mathrm{d}_{3}{ }^{\mathrm{a}}(-)$ & 2.73 & $232.20>169.90$ & 16 \\
\hline & 11.Acethaminophen- $\mathrm{d}_{4}{ }^{\mathrm{d}}(-)$ & 1.90 & $154.19>111.00$ & 17 \\
\hline & 12.Ibuprofen- $\mathrm{d}_{3}{ }^{\mathrm{d}}(-)$ & 2.96 & $208.30>164.00$ & 3 \\
\hline & 13. Carbamazepine- $\mathrm{d}_{10} \mathrm{e}(+)$ & 4.05 & $247.20>204.50$ & 23 \\
\hline & & & $247.20>203.10$ & 23 \\
\hline & 14.Fluoxetine- $\mathrm{d}_{5}{ }^{\mathrm{a}}(+)$ & 4.32 & $315.00>153.00$ & 10 \\
\hline & 15.Gemfibrozil- $\mathrm{d}_{6}^{\mathrm{e}}(-)$ & 3.04 & $255.20>120.50$ & 11 \\
\hline & 16. Albuterol- $\mathrm{d}_{3}{ }^{\mathrm{a}}(+)$ & 2.01 & $243.33>150.90$ & 18 \\
\hline & & & $243.33>224.90$ & 8 \\
\hline & 17. Glibenclamide- $\mathrm{d}_{3}{ }^{\mathrm{e}}(+)$ & 4.76 & $498.03>372.80$ & 16 \\
\hline & & & $498.03>171.80$ & 37 \\
\hline & 18. Hydrochlorothiazide ${ }^{13} \mathrm{C}_{6}{ }^{\mathrm{a}}(-)$ & 1.73 & $302.70>256.50$ & 4 \\
\hline & & & $302.70>210.90$ & 22 \\
\hline
\end{tabular}

\footnotetext{
${ }^{\mathbf{a}}$ Sigma-Aldrich, ${ }^{\mathbf{b}}$ Dr. Ehrenstorfer GmbH, ${ }^{\mathbf{c}}$ Clariant Produkte, ${ }^{\mathbf{d}}$ LGC Standards, ${ }^{\mathbf{e}} \mathrm{CDN}$ Isotopes S.A., ${ }^{\mathbf{f}}$ Cambridge Isotope Laboratories. Inc. Quasimolecular ions different from $[\mathrm{M}+\mathrm{H}]^{+}$: penicillin and monensin: $[\mathrm{M}+\mathrm{Na}]^{+}$, spyramycin: $[\mathrm{M}+2 \mathrm{H}]^{2+}$, ivermectin: $\left[\mathrm{M}+\mathrm{NH}_{4}\right]^{+}$.

Isotopically labelled compounds are indicated by numerated superscript for each compound.
} 


\section{Table 2. Extraction recovery percentages for PhACs by SPE}

\begin{tabular}{|c|c|c|c|}
\hline Compound & $\begin{array}{c}\text { Recovery } \\
(\%)\end{array}$ & Compound & $\begin{array}{c}\text { Recovery } \\
(\%)\end{array}$ \\
\hline Amoxicillin & $18 \pm 3$ & Nitrofurantoin* & $36 \pm 10$ \\
\hline Penicillin-G & $86 \pm 34$ & Metronidazole & $78 \pm 22$ \\
\hline Oxacillin & $17 \pm 3$ & Ornidazole & $60 \pm 16$ \\
\hline Ampicillin & $51 \pm 12$ & Trimethoprim & $90 \pm 21$ \\
\hline Cefaclor & $41 \pm 11$ & Monensin & $86 \pm 6$ \\
\hline Cefdinir & $34 \pm 13$ & Ivermectin & $15 \pm 4$ \\
\hline Ceftiofur & $45 \pm 15$ & Rifampicin & $36 \pm 5$ \\
\hline Cefadroxil & $27 \pm 11$ & Triclocarban & $20 \pm 1$ \\
\hline Cefquinome & $49 \pm 19$ & Triclosan & $53 \pm 0$ \\
\hline Doxycicline & $47 \pm 11$ & Phenazone & $110 \pm 17$ \\
\hline Oxytetracycline* & $84 \pm 24$ & Phenylbutazone & $68 \pm 12$ \\
\hline Chlortetracycline* & $57 \pm 20$ & Acethaminophen & $113 \pm 5$ \\
\hline Tetracycline* & $100 \pm 15$ & Salicylic Acid & $106 \pm 11$ \\
\hline Tiamulin & $70 \pm 16$ & Ketoprofen & $17 \pm 4$ \\
\hline Chloramphenicol & $97 \pm 1$ & Naproxen & $115 \pm 7$ \\
\hline Erythromycin & $92 \pm 15$ & Ibuprofen & $109 \pm 9$ \\
\hline Clarithromycin & $69 \pm 17$ & Fenoprofen & $117 \pm 17$ \\
\hline Azithromycin & $81 \pm 27$ & Indomethacin & $100 \pm 5$ \\
\hline Roxithromycin & $81 \pm 27$ & Diclofenac & $106 \pm 8$ \\
\hline Spiramycin & $27 \pm 4$ & Mefenamic acid & $101 \pm 13$ \\
\hline Tylosin & $68 \pm 12$ & Atenolol & $97 \pm 6$ \\
\hline Lincomycin & $73 \pm 10$ & Metoprolol & $64 \pm 16$ \\
\hline Clindamycin & $44 \pm 11$ & Propanolol & $70 \pm 5$ \\
\hline Sulfamethazine & $69 \pm 9$ & Timolol & $68 \pm 15$ \\
\hline Sulfamethizole & $76 \pm 17$ & Nadolol & $77 \pm 9$ \\
\hline Sulfathiazole & $93 \pm 14$ & Pindolol & $66 \pm 19$ \\
\hline Sulfadiazine & $89 \pm 31$ & Famotidine & $38 \pm 17$ \\
\hline Sulfamethoxazole & $93 \pm 18$ & Ranitidine & $22 \pm 11$ \\
\hline Sulfamethoxyp. & $81 \pm 19$ & Carbamazepine & $104 \pm 15$ \\
\hline Sulfadimethoxine & $109 \pm 23$ & Fluoxetine* & $80 \pm 18$ \\
\hline Sulfisoxazole & $78 \pm 22$ & Amitriptiline* & $100 \pm 7$ \\
\hline Sulfaguanidine & $65 \pm 5$ & Caffeine & $68 \pm 12$ \\
\hline Sulfanilamide & $62 \pm 0$ & Clofibric acid & $73 \pm 3$ \\
\hline Flumequine* & $79 \pm 32$ & Gemfibrozil & $97 \pm 5$ \\
\hline Norfloxacin* & $94 \pm 24$ & Fenofibrate & $17 \pm 4$ \\
\hline Ofloxacin* & $81 \pm 18$ & Bezafibrate & $64 \pm 6$ \\
\hline Ciprofloxacin* & $111 \pm 27$ & Pravastatin & $65 \pm 3$ \\
\hline Enrofloxacin* & $80 \pm 26$ & Albuterol & $113 \pm 7$ \\
\hline Sparfloxacin* & $101 \pm 12$ & Glibenclamide & $146 \pm 9$ \\
\hline Danofloxacin* & $87 \pm 12$ & Metotrexate & $72 \pm 17$ \\
\hline \multirow[t]{2}{*}{ Novobiocin } & $31 \pm 10$ & Hydrochlorot. & $112 \pm 5$ \\
\hline & & Furosemide & $108 \pm 22$ \\
\hline
\end{tabular}




\begin{tabular}{|c|c|c|c|c|c|c|c|c|c|c|c|c|c|c|c|c|c|c|c|c|}
\hline Compound & 01 & $\mathbf{O 2}$ & 04 & M1 & M2 & M3 & M4 & M5 & M6 & M7 & M9 & M10 & M11 & $\mathbf{T 1}$ & $\mathbf{T 2}$ & T3 & J1 & $\mathbf{J 3}$ & J5 & J7 \\
\hline Tiamulin & 0.5 & 0.6 & 0.8 & 0.6 & 0.6 & 0.6 & 0.6 & 0.6 & 0.6 & 1.3 & 0.7 & 0.7 & 0.7 & 0.4 & 0.5 & 0.9 & 0.7 & 0.8 & 0.7 & 0.8 \\
\hline Chloramphenicol & 8.1 & 5.0 & 10.6 & 3.5 & 5.6 & 4.0 & 5.6 & 4.1 & 4.7 & 3.6 & 3.6 & 7.0 & 2.9 & 13.8 & 6.8 & 3.2 & 3.8 & 8.3 & 3.5 & 5.9 \\
\hline Erythromycin & $<\mathrm{LOD}$ & $<\mathrm{LOD}$ & $<\mathrm{LOD}$ & $<\mathrm{LOD}$ & $<\mathrm{LOD}$ & $<\mathrm{LOD}$ & $<\mathrm{LOD}$ & $<\mathrm{LOD}$ & $<\mathrm{LOD}$ & $<\mathrm{LOD}$ & $\angle \mathrm{LOD}$ & $<\mathrm{LOD}$ & $<\mathrm{LOD}$ & $<\mathrm{LOD}$ & $<\mathrm{LOD}$ & $<\mathrm{LOD}$ & $\angle \mathrm{LOD}$ & $<\mathrm{LOD}$ & $<$ LOD & $<$ LOD \\
\hline Lincomycin & 0.8 & 0.4 & 0.5 & 0.7 & 0.4 & 0.4 & 0.4 & 0.4 & 0.3 & 0.5 & 0.6 & 0.6 & 0.4 & 0.5 & 0.8 & 0.7 & 0.6 & 0.5 & 0.6 & 0.6 \\
\hline Clindamycin & 1.0 & 0.9 & 1.1 & 0.9 & 1.0 & 1.6 & 1.1 & 0.9 & 1.0 & 2.2 & 1.4 & 1.3 & 1.5 & 1.0 & 1.3 & 3.8 & 2.4 & $<$ LOD & 1.8 & 1.4 \\
\hline Sulfamethazine & 0.8 & 0.3 & 0.4 & 0.5 & 0.4 & 0.4 & 0.5 & 0.5 & 0.4 & 0.6 & 0.5 & 0.8 & 0.8 & 0.7 & 0.4 & 0.4 & 0.7 & 0.6 & 1.0 & 0.9 \\
\hline Sulfamethizole & 0.2 & $<\mathrm{LOD}$ & $<\mathrm{LOD}$ & $<\mathrm{LOD}$ & $<\mathrm{LOD}$ & 0.1 & $<\mathrm{LOQ}$ & $<\mathrm{LOD}$ & $<\mathrm{LOD}$ & $<\mathrm{LOD}$ & $<\mathrm{LOQ}$ & $<\mathrm{LOD}$ & 0.2 & $<\mathrm{LOQ}$ & 0.3 & $<\mathrm{LOD}$ & 0.1 & $<\mathrm{LOD}$ & $<\mathrm{LOD}$ & $<\mathrm{LOD}$ \\
\hline Sulfathiazole & 0.4 & 0.3 & 0.3 & 0.3 & 0.3 & 0.4 & 0.3 & 0.3 & 0.3 & 0.4 & 0.4 & 0.4 & 0.3 & 0.3 & 0.3 & 0.4 & 0.3 & 0.3 & 0.3 & 0.4 \\
\hline Sulfadiazine & 0.3 & 0.1 & 0.1 & $<\mathrm{LOQ}$ & 0.1 & 0.1 & 0.1 & 0.1 & $<\mathrm{LOQ}$ & 0.1 & 0.1 & 0.2 & 0.1 & 0.1 & 0.1 & 0.1 & 0.1 & $<$ LOQ & 0.1 & 0.2 \\
\hline Sulfamethoxazole & 0.9 & 0.1 & 0.1 & 0.03 & 0.3 & 0.1 & $<\mathrm{LOD}$ & 0.1 & $<\mathrm{LOD}$ & $<\mathrm{LOD}$ & 15.5 & 0.3 & 4.8 & 0.7 & 1.7 & 0.7 & 0.6 & 0.3 & 0.3 & 0.4 \\
\hline Sulfamethoxypyridacine & 0.3 & $<\mathrm{LOD}$ & $<\mathrm{LOD}$ & 0.1 & $<\mathrm{LOQ}$ & $<\mathrm{LOQ}$ & 0.1 & $<\mathrm{LOD}$ & $<\mathrm{LOD}$ & 0.1 & $<\mathrm{LOQ}$ & 0.1 & $<\mathrm{LOD}$ & $<\mathrm{LOQ}$ & $<\mathrm{LOD}$ & $<\mathrm{LOD}$ & $<\mathrm{LOQ}$ & $<\mathrm{LOD}$ & 0.1 & 0.4 \\
\hline Sulfadimethoxine & 0.6 & 0.3 & 0.3 & 0.5 & 0.4 & 0.3 & 0.5 & 0.3 & 0.4 & 0.4 & 0.3 & 0.4 & 0.5 & 0.3 & 0.4 & $<\mathrm{LOD}$ & 0.4 & 0.4 & 0.5 & 0.5 \\
\hline Sulfanilamide & $<\mathrm{LOD}$ & $<\mathrm{LOD}$ & $<\mathrm{LOQ}$ & $<\mathrm{LOD}$ & $<\mathrm{LOQ}$ & $<\mathrm{LOQ}$ & $<\mathrm{LOQ}$ & $<\mathrm{LOQ}$ & $<\mathrm{LOD}$ & $<\mathrm{LOQ}$ & $<\mathrm{LOQ}$ & $<\mathrm{LOD}$ & $<\mathrm{LOQ}$ & $<\mathrm{LOQ}$ & 1.8 & $<\mathrm{LOQ}$ & $<\mathrm{LOQ}$ & $<\mathrm{LOD}$ & $<\mathrm{LOD}$ & $<\mathrm{LOD}$ \\
\hline Flumequine & 1.1 & 0.4 & 0.2 & 0.1 & 0.1 & 0.1 & 0.2 & 0.1 & 0.1 & 0.7 & 0.2 & 0.3 & 0.1 & 0.1 & 0.1 & 0.5 & 0.3 & 0.2 & 0.3 & 0.1 \\
\hline Norfloxacin & 42.9 & 8.2 & $<\mathrm{LOD}$ & $<\mathrm{LOD}$ & $<\mathrm{LOD}$ & $<\mathrm{LOD}$ & $<\mathrm{LOD}$ & $<\mathrm{LOD}$ & $<\mathrm{LOD}$ & $<\mathrm{LOD}$ & $<\mathrm{LOD}$ & $<\mathrm{LOD}$ & $<\mathrm{LOD}$ & $<\mathrm{LOD}$ & $<\mathrm{LOD}$ & $<\mathrm{LOD}$ & $<\mathrm{LOD}$ & $<\mathrm{LOD}$ & $<\mathrm{LOD}$ & $<\mathrm{LOD}$ \\
\hline Ofloxacin & 28.0 & 6.7 & 4.4 & 1.9 & 2.0 & 5.7 & 2.8 & 2.2 & 2.0 & 4.0 & 1.9 & 2.6 & 1.7 & 1.8 & 7.5 & 8.0 & 4.9 & 2.6 & 4.2 & 2.7 \\
\hline Ciprofloxacin & 47.5 & 7.2 & 3.3 & 2.2 & 1.4 & 3.0 & 1.8 & $<\mathrm{LOD}$ & 0.8 & 3.7 & 1.6 & 1.8 & 1.1 & 1.4 & $<\mathrm{LOD}$ & 6.4 & 5.7 & $<\mathrm{LOD}$ & 3.5 & $<\mathrm{LOD}$ \\
\hline Enrofloxacin & 61.7 & 14.9 & 6.2 & 3.3 & 4.9 & 4.4 & 4.2 & 2.9 & 2.5 & 6.3 & 7.0 & 3.8 & $<\mathrm{LOD}$ & $<\mathrm{LOD}$ & $<\mathrm{LOD}$ & $<\mathrm{LOD}$ & 4.4 & 3.5 & 3.8 & 3.0 \\
\hline Sparfloxacin & 11.9 & 2.9 & $<\mathrm{LOD}$ & $<\mathrm{LOD}$ & $<\mathrm{LOD}$ & $<\mathrm{LOD}$ & $<\mathrm{LOD}$ & $<\mathrm{LOD}$ & $<\mathrm{LOD}$ & $<\mathrm{LOD}$ & $<\mathrm{LOD}$ & $<\mathrm{LOD}$ & $<\mathrm{LOD}$ & $<\mathrm{LOD}$ & $<\mathrm{LOD}$ & $<\mathrm{LOD}$ & $<\mathrm{LOD}$ & $<\mathrm{LOD}$ & $<\mathrm{LOD}$ & $<\mathrm{LOD}$ \\
\hline Danofloxacin & 77.3 & 17.1 & 8.1 & 3.0 & 4.6 & 5.0 & 3.2 & 2.0 & 2.7 & 6.2 & 4.7 & 5.5 & 3.2 & 1.0 & 5.5 & $<\mathrm{LOD}$ & 3.8 & 2.6 & 5.0 & 3.3 \\
\hline Metronidazole & 16.3 & 9.8 & 9.1 & 10.4 & 9.6 & 9.2 & 9.9 & 8.6 & 9.6 & 8.6 & $\begin{array}{c}10.7 \\
<\mathrm{LOD}\end{array}$ & 9.0 & 10.0 & 9.3 & 10.0 & 8.4 & 8.3 & 8.1 & 12.1 & 11.8 \\
\hline Nitrofurantoin & $<\mathrm{LOD}$ & $<\mathrm{LOD}$ & $<$ LOD & $<\mathrm{LOD}$ & $<\mathrm{LOD}$ & 18.56 & $<\mathrm{LOD}$ & $<\mathrm{LOD}$ & $<\mathrm{LOD}$ & $<\mathrm{LOD}$ & $<$ LOD & 46.88 & $<\mathrm{LOD}$ & $<\mathrm{LOD}$ & $<\mathrm{LOD}$ & $<$ LOD & $<\mathrm{LOD}$ & $<\mathrm{LOD}$ & $<\mathrm{LOD}$ & 17.6 \\
\hline Trimethoprim & 0.5 & $<\mathrm{LOD}$ & 0.3 & $<\mathrm{LOD}$ & $<\mathrm{LOD}$ & 0.1 & 0.8 & 0.7 & $\begin{array}{l}<\mathrm{LOD} \\
<\mathrm{LOD}\end{array}$ & 1.1 & 0.1 & 1.6 & 1.0 & 0.8 & 2.0 & 0.2 & 2.0 & 0.3 & 1.8 & 0.6 \\
\hline Monensin & 0.3 & $<\mathrm{LOQ}$ & $<\mathrm{LOD}$ & 0.1 & $<\mathrm{LOD}$ & $<\mathrm{LOD}$ & $<\mathrm{LOD}$ & $<\mathrm{LOQ}$ & $\begin{array}{c}\text { <UD } \\
-\end{array}$ & $<\mathrm{LOD}$ & $<\mathrm{LOD}$ & 0.2 & $<\mathrm{LOQ}$ & $<\mathrm{LOQ}$ & 0.1 & $<\mathrm{LOD}$ & 0.3 & $<\mathrm{LOQ}$ & 0.4 & 0.1 \\
\hline Triclocarban & $<\mathrm{LOD}$ & $<\mathrm{LOD}$ & $<\mathrm{LOD}$ & $<\mathrm{LOD}$ & $<\mathrm{LOD}$ & $<\mathrm{LOD}$ & $<\mathrm{LOD}$ & $<\mathrm{LOD}$ & $<\mathrm{LOD}$ & $<\mathrm{LOD}$ & $<\mathrm{LOD}$ & $<\mathrm{LOD}$ & $<\mathrm{LOD}$ & $<\mathrm{LOD}$ & $<\mathrm{LOD}$ & $<$ LOD & $<\mathrm{LOD}$ & 1.3 & $<\mathrm{LOD}$ & $<$ LOD \\
\hline Triclosan & $<\mathrm{LOD}$ & $<\mathrm{LOD}$ & $<\mathrm{LOD}$ & $<\mathrm{LOD}$ & $<\mathrm{LOD}$ & $<\mathrm{LOD}$ & $<\mathrm{LOD}$ & $<\mathrm{LOD}$ & $<\mathrm{LOD}$ & $<\mathrm{LOD}$ & $<\mathrm{LOD}$ & $<\mathrm{LOD}$ & $<\mathrm{LOD}$ & $<\mathrm{LOD}$ & $<\mathrm{LOD}$ & $<\mathrm{LOD}$ & $<\mathrm{LOD}$ & 7.9 & $<\mathrm{LOD}$ & $<\mathrm{LOD}$ \\
\hline Acethaminophen & $<\mathrm{LOD}$ & $<\mathrm{LOQ}$ & $<\mathrm{LOQ}$ & $<\mathrm{LOQ}$ & $<\mathrm{LOD}$ & $<\mathrm{LOD}$ & $<\mathrm{LOQ}$ & $<\mathrm{LOQ}$ & $<\mathrm{LOQ}$ & $<\mathrm{LOQ}$ & 2.0 & 2.2 & 33.7 & 11.4 & 75.6 & 13.6 & $<\mathrm{LOQ}$ & $<\mathrm{LOD}$ & $<\mathrm{LOQ}$ & $<\mathrm{LOD}$ \\
\hline Diclofenac & 1.9 & $<\mathrm{LOD}$ & 7.8 & $<\mathrm{LOD}$ & $<\mathrm{LOD}$ & $<\mathrm{LOD}$ & $<\mathrm{LOD}$ & 1.5 & $<\mathrm{LOD}$ & $<\mathrm{LOD}$ & 3.1 & $<\mathrm{LOD}$ & 5.5 & 9.2 & 10.7 & 2.2 & 1.6 & 6.2 & $<\mathrm{LOD}$ & 0.3 \\
\hline Fenoprofen & 5.9 & 6.5 & $<\mathrm{LOD}$ & $<\mathrm{LOD}$ & $<\mathrm{LOD}$ & $<\mathrm{LOD}$ & $<\mathrm{LOD}$ & $<\mathrm{LOD}$ & $<\mathrm{LOD}$ & $<\mathrm{LOD}$ & 6.9 & 7.5 & 6.7 & $<\mathrm{LOD}$ & $<\mathrm{LOD}$ & $<\mathrm{LOD}$ & 8.7 & 20.6 & 8.3 & 7.2 \\
\hline Ibuprofen & $<\mathrm{LOD}$ & 8.8 & $<\mathrm{LOD}$ & 9.0 & 8.4 & 8.5 & 6.9 & 8.2 & 8.7 & 4.3 & 181.8 & 11.3 & 195.0 & 33.7 & 136.0 & 39.6 & 15.3 & 9.3 & $<\mathrm{LOQ}$ & $<\mathrm{LOD}$ \\
\hline Indomethacin & $<\mathrm{LOQ}$ & 2.2 & 2.5 & 3.2 & 2.4 & $<\mathrm{LOQ}$ & 2.5 & 2.3 & 2.1 & $<\mathrm{LOQ}$ & $<\mathrm{LOQ}$ & 2.5 & $<\mathrm{LOD}$ & 7.7 & 5.8 & 4.1 & 3.6 & 3.6 & 3.4 & $<\mathrm{LOQ}$ \\
\hline
\end{tabular}




\begin{tabular}{|c|c|c|c|c|c|c|c|c|c|c|c|c|c|c|c|c|c|c|c|c|}
\hline Mefenamic acid & 7.5 & 8.9 & 10.8 & 12.2 & 8.0 & 11.0 & 8.2 & 12.7 & 9.8 & 14.6 & 6.5 & 10.9 & 8.8 & 24.6 & 14.8 & 7.5 & 17.6 & 29.2 & 12.7 & 13.3 \\
\hline Naproxen & 3.2 & 2.8 & 1.8 & 4.0 & 3.3 & 4.7 & 3.7 & 3.1 & 3.3 & 1.1 & 69.7 & 4.8 & 57.3 & 15.2 & 35.9 & 12.5 & 4.3 & 5.7 & 2.0 & $<\mathrm{LOD}$ \\
\hline Phenylbutazone & 3.4 & $<\mathrm{LOD}$ & $<\mathrm{LOD}$ & $<\mathrm{LOQ}$ & $<\mathrm{LOQ}$ & $<\mathrm{LOQ}$ & $<\mathrm{LOQ}$ & $<\mathrm{LOQ}$ & $<\mathrm{LOQ}$ & $<\mathrm{LOQ}$ & $<\mathrm{LOQ}$ & $<\mathrm{LOQ}$ & $<\mathrm{LOQ}$ & 2.80 & 2.89 & $<\mathrm{LOQ}$ & 1.44 & 2.85 & $<$ LOQ & 3.07 \\
\hline Salicilic acid & 17.5 & 5.5 & 13.7 & 6.0 & 4.7 & $<\mathrm{LOQ}$ & 6.4 & 5.1 & 8.5 & 6.4 & 5.5 & 5.9 & 15.8 & 16.3 & 10.5 & 5.5 & 7.8 & 29.4 & 4.9 & 4.3 \\
\hline Atenolol & 4.0 & 3.3 & 3.3 & 1.9 & 2.4 & 3.4 & 2.6 & 2.5 & 2.5 & 0.5 & 24.9 & 2.7 & 40.9 & 9.1 & 21.7 & 15.8 & 4.2 & 2.8 & 2.1 & 0.3 \\
\hline Nadolol & $<\mathrm{LOD}$ & $<\mathrm{LOD}$ & $<\mathrm{LOD}$ & $<\mathrm{LOD}$ & $<\mathrm{LOD}$ & $<\mathrm{LOD}$ & $<\mathrm{LOD}$ & $<\mathrm{LOD}$ & $<\mathrm{LOD}$ & $<\mathrm{LOD}$ & 0.5 & $<\mathrm{LOD}$ & 0.9 & 0. & $<\mathrm{LOD}$ & 0.6 & $<\mathrm{LOD}$ & 0.1 & $<\mathrm{LOD}$ & $<\mathrm{LOD}$ \\
\hline Carbamazepine & 0.6 & 0.4 & 0.3 & 0.4 & 0.3 & 0.3 & 0.2 & 0.3 & 0.3 & 0.1 & 0.9 & 0.3 & 1.6 & 0.7 & 1.1 & 1.0 & 0.5 & 0.4 & 0.4 & 0.2 \\
\hline Amitriptiline & 0.3 & 0.4 & 0.6 & $<\mathrm{LOD}$ & $<\mathrm{LOD}$ & $<\mathrm{LOD}$ & $<\mathrm{LOD}$ & $<$ LOD & $<\mathrm{LOD}$ & $<\mathrm{LOD}$ & 0.5 & $<\mathrm{LOD}$ & $<\mathrm{LOD}$ & 0.2 & 0.4 & 0.3 & 0.2 & $<\mathrm{LOD}$ & $<\mathrm{LOD}$ & $<$ LOD \\
\hline Caffeine & 39.6 & 17.4 & 13.2 & 20.9 & 21.8 & 15.7 & 11.3 & 52.1 & 20.1 & 10.5 & 182.3 & 20.2 & 522.0 & 30.2 & 107.8 & 59.0 & 20.7 & 18.4 & 25.8 & 7.2 \\
\hline Gemfibrozil & 1.5 & 6.6 & 1.1 & 9.0 & 6.9 & 6.7 & 5.4 & 6.8 & 5.1 & 1.2 & 46.7 & 9.1 & 64.8 & 29.8 & 69.2 & 22.3 & 12.8 & 8.9 & 5.8 & 1.4 \\
\hline Bezafibrate & $<\mathrm{LOD}$ & 0.6 & $<\mathrm{LOD}$ & 0.4 & 0.4 & 0.6 & 0.5 & 0.4 & 0.3 & $<\mathrm{LOD}$ & 5.6 & 0.4 & 5.2 & 2.2 & 2.8 & 1.3 & 0.5 & 0.6 & 0.2 & $<\mathrm{LOD}$ \\
\hline Clofibric acid & 0.5 & 1.4 & $<\mathrm{LOD}$ & 0.4 & 0.4 & 0.3 & 0.3 & 0.3 & 0.3 & 0.3 & 0.7 & 0.4 & 0.8 & 1.5 & 2.2 & 0.9 & 0.4 & 0.9 & 0.3 & 0.2 \\
\hline Furosemide & 8.4 & 7.4 & 9.5 & 1.0 & 1.0 & 6.5 & 6.1 & 5.3 & 4.9 & 1.8 & 10.6 & $<\mathrm{LOD}$ & 8.2 & 5.7 & 29.8 & 4.5 & 6.1 & 11.0 & 2.3 & $<\mathrm{LOD}$ \\
\hline Hydrochlorothiazide & 3.8 & 4.1 & 1.8 & 1.8 & 1.4 & 3.5 & 2.1 & 3.0 & 2.6 & $<\mathrm{LOD}$ & 20.7 & 4.1 & 41.0 & 63.1 & 167.6 & 38.8 & 7.9 & 3.8 & 2.0 & $<\mathrm{LOD}$ \\
\hline
\end{tabular}




\begin{tabular}{|c|c|c|c|c|c|c|c|c|c|c|c|c|c|c|c|c|c|}
\hline Compound & E0 & E6 & E8 & P1 & R7 & S8 & T6 & U2 & U4 & U8 & V1 & W2 & W6 & W7 & X3 & X5 & Y4 \\
\hline Doxycicline & $<\mathrm{LOD}$ & $<\mathrm{LOD}$ & $<\mathrm{LOD}$ & 3.5 & $<\mathrm{LOD}$ & $<\mathrm{LOD}$ & $<\mathrm{LOD}$ & $<\mathrm{LOD}$ & $<\mathrm{LOD}$ & $<\mathrm{LOD}$ & $<\mathrm{LOD}$ & $<\mathrm{LOD}$ & $<\mathrm{LOD}$ & $<\mathrm{LOD}$ & $<\mathrm{LOD}$ & $<\mathrm{LOD}$ & $<\mathrm{LOD}$ \\
\hline Oxytetracycline & $<\mathrm{LOD}$ & $<\mathrm{LOD}$ & $<\mathrm{LOD}$ & 2.3 & $<\mathrm{LOD}$ & $<\mathrm{LOD}$ & 2.4 & $<\mathrm{LOD}$ & $<\mathrm{LOD}$ & $<\mathrm{LOD}$ & $<\mathrm{LOD}$ & $<\mathrm{LOD}$ & $<\mathrm{LOD}$ & $<\mathrm{LOD}$ & $<\mathrm{LOD}$ & $<\mathrm{LOD}$ & $<\mathrm{LOD}$ \\
\hline Tetracycline & 1.4 & 0.7 & 1.7 & 1.6 & 2.2 & 1.4 & 1.9 & 1.4 & 0.7 & 0.9 & 1.8 & 1.5 & 1.5 & 0.8 & 1.3 & 1.1 & 2.4 \\
\hline Tiamulin & 0.7 & 0.7 & 0.8 & 0.6 & 1.0 & 1.2 & 4.5 & 0.8 & 1.0 & 0.8 & 0.7 & 0.5 & 0.6 & 0.7 & 0.5 & 1.1 & 0.6 \\
\hline Chloramphenicol & 3.0 & 1.9 & 2.4 & 2.2 & 1.7 & 2.0 & $<\mathrm{LOD}$ & 5.0 & 2.7 & 6.0 & 1.5 & $<\mathrm{LOD}$ & $<\mathrm{LOD}$ & 4.3 & 2.8 & 2.9 & 2.1 \\
\hline Erythromycin & $<\mathrm{LOD}$ & $<$ LOD & $<\mathrm{LOD}$ & $<\mathrm{LOD}$ & $<\mathrm{LOQ}$ & $<\mathrm{LOD}$ & $<\mathrm{LOD}$ & $<\mathrm{LOD}$ & $<\mathrm{LOD}$ & $<\mathrm{LOD}$ & $<\mathrm{LOD}$ & $<\mathrm{LOD}$ & $<\mathrm{LOD}$ & $<\mathrm{LOD}$ & $<\mathrm{LOD}$ & $<\mathrm{LOD}$ & $<\mathrm{LOD}$ \\
\hline Lincomycin & 0.2 & 0.5 & 0.2 & 0.2 & 0.7 & 0.3 & 0.4 & 0.5 & 0.3 & 0.6 & 0.3 & 0.3 & 0.2 & 0.1 & 0.5 & 0.2 & 0.2 \\
\hline Clindamycin & 1.2 & 1.3 & 1.4 & 1.0 & 1.3 & 2.0 & 3.2 & 1.2 & 1.5 & 1.3 & 1.2 & 1.0 & 1.1 & 1.6 & 0.9 & 9.6 & 0.8 \\
\hline Sulfamethazine & 0.3 & 0.9 & 0.4 & 0.3 & 0.3 & 0.4 & 0.3 & 0.5 & 0.3 & 0.2 & 0.3 & 0.1 & 02 & 0.3 & 0.5 & 0.1 & 0.5 \\
\hline Sulfamethizole & $<\mathrm{LOD}$ & 0.1 & $<\mathrm{LOD}$ & $<\mathrm{LOD}$ & 0.1 & $<\mathrm{LOD}$ & $<\mathrm{LOD}$ & $<\mathrm{LOD}$ & $<\mathrm{LOD}$ & $<\mathrm{LOD}$ & $<\mathrm{LOD}$ & $<\mathrm{LOD}$ & $<\mathrm{LOD}$ & $<\mathrm{LOD}$ & $<\mathrm{LOD}$ & $<\mathrm{LOD}$ & $<$ LOD \\
\hline Sulfathiazole & 0.4 & 0.5 & 0.3 & 0.3 & 0.4 & 0.4 & 0.3 & 0.4 & 0.5 & 0.4 & 0.3 & 0.3 & 0.3 & 0.3 & 0.3 & 0.3 & 0.3 \\
\hline Sulfadiazine & 0.54 & 0.3 & 0.1 & 0.2 & 0.3 & 0.5 & 0.3 & 0.2 & 0.3 & 0.3 & 0.3 & 0.1 & 0.1 & 0.1 & 0.3 & 0.2 & 0.1 \\
\hline Sulfamethoxazole & $<\mathrm{LOD}$ & 0.2 & $<$ LOQ & $<\mathrm{LOD}$ & 0.2 & $<\mathrm{LOD}$ & $<\mathrm{LOD}$ & 0.1 & 0.1 & $<\mathrm{LOD}$ & $<\mathrm{LOD}$ & $<\mathrm{LOD}$ & $<\mathrm{LOD}$ & $<\mathrm{LOD}$ & 0.1 & $<\mathrm{LOD}$ & $<\mathrm{LOD}$ \\
\hline Sulfamethoxypyridacine & $<\mathrm{LOD}$ & 0.5 & $<\mathrm{LOD}$ & $<\mathrm{LOD}$ & 0.4 & $<\mathrm{LOD}$ & $<\mathrm{LOD}$ & $<\mathrm{LOQ}$ & 0.2 & $<\mathrm{LOQ}$ & $<\mathrm{LOD}$ & $<\mathrm{LOD}$ & $<\mathrm{LOD}$ & $<\mathrm{LOD}$ & 0.1 & $<\mathrm{LOD}$ & $<\mathrm{LOD}$ \\
\hline Sulfadimethoxine & 0.4 & 0.7 & 0.3 & 0.4 & 0.7 & 0.5 & 0.3 & 0.5 & 0.5 & 0.5 & 0.3 & 0.3 & 0.3 & 0.4 & 0.4 & 0.3 & 0.4 \\
\hline Norfloxacin & 8.7 & 5.8 & 2.9 & 5.2 & 1.9 & $<\mathrm{LOD}$ & 8.6 & 1.2 & 2.6 & 6.1 & $<\mathrm{LOD}$ & 2.1 & 2.3 & 3.8 & $<\mathrm{LOD}$ & 4.9 & 1.0 \\
\hline Ofloxacin & 3.1 & 3.2 & 2.5 & 4.2 & $<\mathrm{LOD}$ & 2.8 & 8.5 & 3.5 & 31 & 4.8 & 2.1 & 1.3 & $<\mathrm{LOD}$ & 1.7 & $<\mathrm{LOD}$ & 4.2 & $<\mathrm{LOD}$ \\
\hline Ciprofloxacin & $<\mathrm{LOD}$ & $<\mathrm{LOD}$ & $<\mathrm{LOD}$ & 2.2 & $<\mathrm{LOD}$ & $<\mathrm{LOD}$ & 6.9 & 4.6 & $<\mathrm{LOD}$ & 6.1 & $<\mathrm{LOD}$ & $<\mathrm{LOD}$ & $<\mathrm{LOD}$ & $<\mathrm{LOD}$ & $<\mathrm{LOD}$ & $<\mathrm{LOD}$ & $<\mathrm{LOD}$ \\
\hline Enrofloxacin & $<\mathrm{LOD}$ & $<\mathrm{LOD}$ & 3.4 & 3.2 & $<\mathrm{LOD}$ & $<\mathrm{LOD}$ & 9.1 & $<\mathrm{LOD}$ & $<\mathrm{LOD}$ & $<\mathrm{LOD}$ & 3.1 & $<\mathrm{LOD}$ & 15.4 & $<\mathrm{LOD}$ & 1.9 & 6.7 & $<\mathrm{LOD}$ \\
\hline Danofloxacin & 1.4 & 1.8 & 2.8 & 5.0 & 3.0 & $<\mathrm{LOD}$ & 10.0 & 3.4 & 4.1 & 6.0 & 2.6 & $<\mathrm{LOD}$ & $<\mathrm{LOD}$ & $<\mathrm{LOD}$ & $<\mathrm{LOD}$ & $<\mathrm{LOD}$ & $<\mathrm{LOD}$ \\
\hline Metronidazole & 8.2 & 11.1 & 7.7 & 6.5 & 13.6 & 9.7 & 7.8 & 14.8 & 11.2 & 7.5 & 9.4 & 7.1 & 6.0 & 9.3 & 7.0 & 5.4 & 8.5 \\
\hline Ornidazole & $<\mathrm{LOD}$ & $<\mathrm{LOD}$ & $<\mathrm{LOD}$ & $<\mathrm{LOD}$ & $<\mathrm{LOD}$ & $<\mathrm{LOD}$ & 1.4 & 0.1 & $<\mathrm{LOD}$ & $<\mathrm{LOQ}$ & $<\mathrm{LOD}$ & $<\mathrm{LOD}$ & $<\mathrm{LOD}$ & $<$ LOQ & $<\mathrm{LOD}$ & $<\mathrm{LOD}$ & $<\mathrm{LOD}$ \\
\hline Nitrofurantoin & $<\mathrm{LOD}$ & $<\mathrm{LOD}$ & $<\mathrm{LOD}$ & $<\mathrm{LOD}$ & 12.4 & $<\mathrm{LOD}$ & $<\mathrm{LOD}$ & $<\mathrm{LOD}$ & $<\mathrm{LOD}$ & $<\mathrm{LOD}$ & $<\mathrm{LOD}$ & $<\mathrm{LOD}$ & $<\mathrm{LOD}$ & $<\mathrm{LOD}$ & 9.6 & $<\mathrm{LOD}$ & $<\mathrm{LOD}$ \\
\hline Trimethoprim & $<\mathrm{LOD}$ & 0.3 & $<\mathrm{LOD}$ & $<\mathrm{LOD}$ & $<\mathrm{LOD}$ & $<\mathrm{LOD}$ & 1.9 & 0.5 & $<\mathrm{LOQ}$ & $<\mathrm{LOD}$ & $<\mathrm{LOD}$ & $<\mathrm{LOD}$ & $<\mathrm{LOD}$ & $<\mathrm{LOD}$ & $<\mathrm{LOD}$ & 3.3 & $<\mathrm{LOD}$ \\
\hline Monensin & 0.1 & 0.1 & 0.2 & 0.3 & 0.3 & 0.2 & 0.3 & 0.3 & 0.1 & 0.2 & 0.6 & 0.4 & 0.3 & 0.2 & 0.3 & 1.0 & 0.3 \\
\hline Triclocarban & 0.9 & 0.4 & 0.4 & 1.1 & 0.8 & 0.7 & $<\mathrm{LOD}$ & 1.0 & 0.7 & 0.3 & $<\mathrm{LOD}$ & $<\mathrm{LOQ}$ & 0.2 & $<\mathrm{LOD}$ & 1.3 & 0.7 & 0.4 \\
\hline Triclosan & 3.6 & 0.6 & $<\mathrm{LOQ}$ & 3.6 & 6.3 & 6.9 & 4.9 & 16.1 & 1.0 & 2.8 & 1.3 & 4.2 & 1.9 & 0.02 & 4.6 & 11.3 & 5.7 \\
\hline Acethaminophen & 2.6 & $<\mathrm{LOQ}$ & 8.0 & 5.4 & 0.6 & $<\mathrm{LOD}$ & 6.4 & $<\mathrm{LOQ}$ & $<\mathrm{LOD}$ & $<\mathrm{LOQ}$ & 3.9 & 7.1 & 2.6 & $<\mathrm{LOD}$ & 2.6 & $<\mathrm{LOQ}$ & $<\mathrm{LOD}$ \\
\hline Diclofenac & 12.5 & 3.9 & 3.1 & 9.0 & 12.9 & 16.0 & 12.1 & 4.1 & 5.1 & 13.5 & 21.2 & $<\mathrm{LOD}$ & 9.1 & 4.2 & 26.0 & 6.1 & 27.6 \\
\hline Fenoprofen & 31.9 & $<\mathrm{LOD}$ & 7.7 & 4.4 & 8.3 & 29.6 & 11.7 & 17.7 & 2.6 & 16.7 & 20.2 & $<\mathrm{LOD}$ & $<\mathrm{LOD}$ & 14.8 & 5.8 & $<\mathrm{LOD}$ & 25.7 \\
\hline Ibuprofen & 4.5 & $<\mathrm{LOQ}$ & 18.3 & 4.4 & 3.4 & $<\mathrm{LOQ}$ & 4.5 & 2.8 & $<\mathrm{LOD}$ & $<\mathrm{LOQ}$ & 7.8 & 6.3 & 3.5 & $<\mathrm{LOQ}$ & 4.9 & $<\mathrm{LOQ}$ & 3.7 \\
\hline Indomethacin & $<\mathrm{LOD}$ & $<\mathrm{LOD}$ & $<$ LOD & $<\mathrm{LOD}$ & $<\mathrm{LOD}$ & $<\mathrm{LOD}$ & $<\mathrm{LOD}$ & $<\mathrm{LOD}$ & $<\mathrm{LOD}$ & $<\mathrm{LOD}$ & $<\mathrm{LOD}$ & $<\mathrm{LOD}$ & $<\mathrm{LOQ}$ & $<\mathrm{LOD}$ & $<\mathrm{LOQ}$ & $<\mathrm{LOQ}$ & 3.79 \\
\hline
\end{tabular}




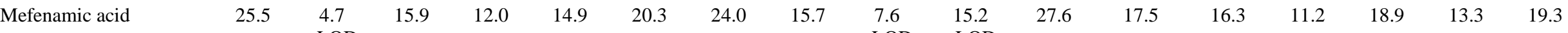

$\begin{array}{lllllllllllllllllll}\text { Naproxen } & 1.3 & <\mathrm{LOD} & 2.6 & 2.2 & 1.0 & 0.9 & 2.6 & 1.2 & <\mathrm{LOD} & <\mathrm{LOD} & 2.3 & 2.5 & 2.1 & <\mathrm{LOD} & 1.7 & 1.3 & <\mathrm{LOD}\end{array}$

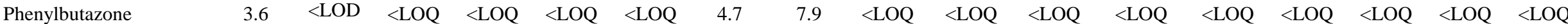

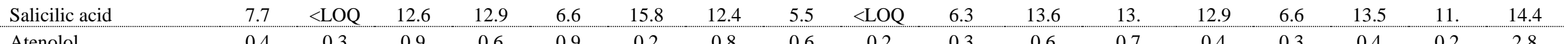

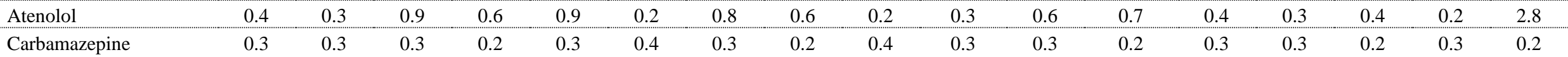

$\begin{array}{llllllllllllllllll}\text { Caffeine } & 11.9 & 12.3 & 24.3 & 15.9 & 37.9 & 15.6 & 20.8 & 11.7 & 9.8 & 14.2 & 17.3 & 23.0 & 42.9 & 11.8 & 16.8 & 14.6 & 15.21\end{array}$

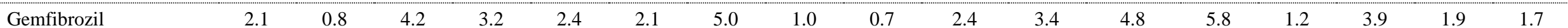

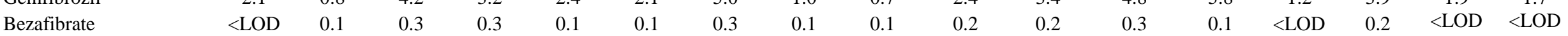

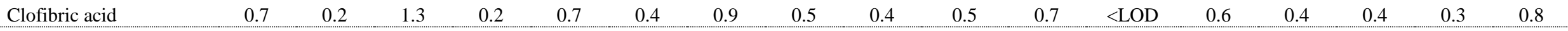

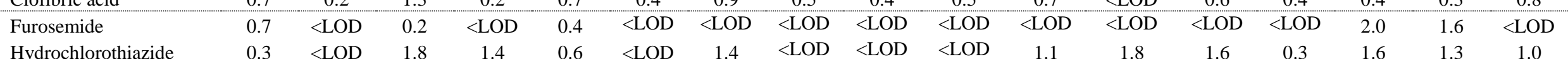

Hydrochlorothiazide

$0.3 \quad<$ LOD $\quad 1.8 \quad 1.4 \quad 0.6$

$\begin{array}{ll}<\mathrm{LOD} & <\mathrm{LO} \\ 0.6 & <\mathrm{LOD}\end{array}$

$<$ LOD

$\begin{array}{cccccc}\text { LOD } & <\text { LOD } & <\text { LOD } & 2.0 & 1.6 & <\text { LOD } \\ 1.8 & 1.6 & 0.3 & 1.6 & 1.3 & 1.0\end{array}$

